\title{
REDECA
}

CI ÊNCIAS CONTÁBEIS

ATUÁRIA E MÉTODOS QUANTITATIVOS

\section{PLANEJAMENTO TRIBUTÁRIO COM ÊNFASE NA LEI COMPLEMENTAR No 155/16: UM ESTUDO DE CASO EM UMA EMPRESA PRESTADORA DE SERVIÇO DE FONOAUDIOLOGIA DA CIDADE DE MOSSORÓ/RN.}

\author{
Victor Afonso Linhares Lima Leite ${ }^{1}$ \\ Moises Ozório de Souza Neto ${ }^{2}$ \\ José Mauro Madeiros Velôso Soares ${ }^{3}$
}

\begin{abstract}
Resumo
O Brasil possui uma alta carga tributária, sendo que no ano de 2017, a carga tributária bruta atingiu o equivalente a 32,36\% do PIB. Além da elevada carga tributária, o Brasil possui, ainda, um sistema tributário complexo, gerando insegurança jurídica para os contribuintes quanto ao cumprimento ou não das obrigações principais e acessórias. Diante deste cenário o presente estudo tem como objetivo analisar a melhor maneira para um empresário individual com atuação na prestação de serviços de fonoaudiologia localizada na cidade de Mossoró/RN apurar seus tributos. Para tanto, esta pesquisa foi realizada por meio de um estudo de caso, classificando-se como descritiva, documental e qualitativa. Os resultados apontaram que a melhor maneira para um empresário individual prestador de serviço de Fonoaudiologia apurar seus tributos é optando pelo Simples Nacional o com Fator R igual ou superior a $28 \%$. Verificou-se também que as atividades tributadas pelo extinto anexo VI sofreram uma redução na carga tributária a partir da vigência da $\operatorname{LC} \mathrm{n}^{\circ} 155 / 16$, a redução torna-se ainda maior, caso a empresa possua despesas com folha de pagamento e encargos sobre ela incidente maiores que 28\%. A principal contribuição está em demonstrar ao empresário a importância da elaboração de um planejamento tributário bem formulado no intuito de diminuir as despesas tributárias.
\end{abstract}

Palavras-chave: Planejamento Tributário; Regimes Tributários; Contabilidade Tributária.

\footnotetext{
${ }^{1}$ Graduado em Ciências Contábeis pela Universidade Federal Rural do Semi-Árido.

${ }^{2}$ Doutorando em Ciências Contabeis pela Universidade do Vale do Rio dos Sinos.

${ }^{3}$ Doutorando em Ciências Contabeis pela Universidade do Vale do Rio dos Sinos.
} 


\title{
REDECA
}

\section{CIÊNCIAS CONTÁBEIS}

\begin{abstract}
Brazil has a high tax burden, and in 2017, the gross tax burden reached the equivalent of $32.36 \%$ of GDP. In addition to the high tax burden, Brazil also has a complex tax system, generating legal uncertainty for taxpayers as to whether or not the principal and accessory obligations are met. Given this scenario, the present study aims to analyze the best way for an individual entrepreneur with a role in providing speech therapy services located in Mossoró / RN to determine their taxes. Therefore, this research was performed through a case study, classified as a descriptive, documentary, and qualitative. The results pointed out that the best way for an individual entrepreneur to provide Speech and Hearing services is to opt for National Simples o with Factor R equal to or greater than $28 \%$. It was also verified that the activities taxed by the extinct annex VI suffered a reduction in the tax burden as of the validity of LC 155/16, the decline becomes even higher if the company has expenses with payroll and charges on it incident greater than $28 \%$. The main contribution is to demonstrate to the entrepreneur the importance of the elaboration of a well-formulated tax planning to reduce tax expenses.
\end{abstract}

Keywords: Tax Planning; Tax Regimes; Tax Accounting. 
Rosa, F. C., Mandu, T. O., Grecco, M. C. P., Silva, F. L., Antunes, M. T. P.; Relação entre o Valor Adicionado distribuído e a satisfação dos Funcionários

\section{Introdução}

O Brasil é visto tanto pelos contribuintes como pelos principais autores da matéria tributaria como sendo um país que possui um sistema tributário complexo e com elevado ônus fiscal, gerando assim um alto custo aos contribuintes e ainda uma constante insegurança de estar ou não cumprido todas as obrigações exigidas pelo fisco. Dessa forma, as empresas acabam comprometendo boa parte de suas receitas para pagamento de tributos e o cumprimento das obrigações acessórias. De acordo com dados divulgados pela Receita Federal (2016) a Carga Tributária Bruta (CTB) atingiu 32,38\% do PIB, contra 32,11\% no ano de 2015, indicando uma variação positiva de 0,27 pontos percentual. Ainda de acordo com a Receita Federal (2017), a carga tributária se manteve instável atingindo 32,36\% do PIB. Um estudo realizado pelo Instituto Brasileiro de Planejamento e Tributação [IBPT] (2017) constatou que o Brasil é o país com pior retorno à população nas esferas federal, estadual e municipal, quando comparado aos 30 países que possuem as maiores cargas tributárias do mundo, em relação às áreas de saúde, educação e segurança.

Outra característica do sistema tributário brasileiro é o grande número de normas editadas ao longo dos anos. Em outro estudo realizado pelo IBPT (2015), desde 05 de outubro de 1988 (data da promulgação da atual Constituição Federal) até 31 de agosto de 2013, foram editadas no Brasil 4.785.194 normas que regem a vida dos cidadãos brasileiros. O que representa, em média, 524 normas editadas todos os dias ou 784 normas editadas por dias úteis. Do total das normas editadas no Brasil nesses 25 anos, 6,5\% se refere à matéria tributária. São 29.939 normas tributárias federais $(9,68 \%$ das normas tributárias), 96.062 normas tributárias estaduais $(30,10 \%$ das normas tributárias) e 186.146 normas municipais $(60,21 \%$ das normas tributárias). Em média foram editadas 31 normas tributárias/dia ou 1,29 normas tributárias por hora. Das 309.147 normas tributárias editadas, 7,6\% (ou 23.412) estavam em vigor até 01 de outubro de 2013.

Diante deste sistema tão complexo e constantemente modificado, a Constituição Federal (1988) em seu o art. 179 assegura tratamento diferenciado e favorecido às Microempresas (ME) e Empresas de Pequeno Porte (EPP). Tal medida visa impulsionar a atuação e a permanência das Micro e Pequenas empresas no mercado. Atendendo a esta disposição constitucional foi editada a Lei Complementar $n^{\circ}$ 123/06, instituindo o Estatuto Nacional da Microempresa e da Empresa de Pequeno Porte, o Simples Nacional. Posteriormente, com a edição da Lei Complementar $\mathrm{n}^{\circ}$ 128/08, tal sistema foi ampliado e surgiu a figura dos Microempreendedores Individuais (MEI). A última alteração no Simples Nacional se deu por meio da Lei Complementar $\mathrm{n}^{\circ} 155$ de 27 de Outubro de 2016.

Segundo Chaves (2014), uma alternativa para diminuir o ônus fiscal, tanto para as novas empresas como as que já estão ativas no mercado é a elaboração de um Planejamento Tributário, uma vez que visa à economia de tributos ao analisar as alternativas tributárias e dentre estas optar pela menos onerosa. Desta forma, o Planejamento Tributário torna-se indispensável para as empresas que pretendem manter-se competitiva no mercado, levando em consideração que a gestão fiscal gera vantagem diante dos seus concorrentes.

Criado há aproximadamente 12 anos, o Simples Nacional tornou-se um forte aliado das Microempresas e Empresas de Pequeno Porte, contribuindo de forma positiva para o sucesso destas. Segundo Wilbert, De Alcântara e Serrano (2015) com o surgimento do Simples, a arrecadação das ME, EPP e MEI cresceram significativamente entre 2007 e 2013, sendo responsável por mais da metade da geração de empregos no país. 
Rosa, F. C., Mandu, T. O., Grecco, M. C. P., Silva, F. L., Antunes, M. T. P.; Relação entre o Valor Adicionado distribuído e a satisfação dos Funcionários

Deste modo, com um mercado cada vez mais competitivo e globalizado torna-se necessário que as empresas busquem sempre o desenvolvimento de um planejamento tributário visando, assim, à redução dos encargos tributários. Analisando os dados de um empresário individual, pergunta-se: Qual a melhor forma para um empresário individual com atuação na prestação de serviços de Fonoaudiologia na cidade de Mossoró/RN apurar seus tributos após a $\mathrm{LC} \mathrm{n}^{0}$ 155/16?

Diante disto, a presente pesquisa tem por objetivo analisar a melhor maneira para um empresário individual com atuação na prestação de serviços de fonoaudiologia localizada na cidade de Mossoró/RN apurar seus tributos. Para que se possa atingir o objetivo geral do estudo, faz-se necessário estabelecer os seguintes objetivos específicos: a) verificar a tributação entre julho de 2017 a junho de 2018; b) comparar os regimes tributários Lucro Presumido e Simples Nacional.

A presente pesquisa busca contribuir com a literatura brasileira já existente, uma vez que, estudos a respeito de planejamento tributário voltado as empresas prestadoras de serviço ainda são escassos. Dessa forma, este estudo visa servir de base para pesquisas relacionadas com o tema. Esta pesquisa justifica-se de forma prática, ao contribuir com a classe contábil bem como os novos contadores evidenciando as mudanças ocorridas no Simples Nacional a partir da $\mathrm{LC} \mathrm{n}^{\circ}$ 155/16. Demonstrando assim, a relevância do planejamento tributário bem formulado e executado pelas Microempresas e Empresas de Pequeno Porte para redução do ônus tributário e, consequentemente, a maximização dos resultados.

\section{Referencial Teórico}

\subsection{Planejamento Tributário}

A contabilidade na condição de ciência social aplicada encontra-se em constate evolução, tal evolução se deve ao fato das necessidades de a sociedade também mudarem ao longo dos anos. Iudícibus (2010) aponta a importância da contabilidade na gestão fiscal. O autor ressalta ainda a importância da contabilidade na gestão tributária. Tal importância se deve ao fato de duas características do sistema tributário brasileiro, sendo elas: o elevado ônus fiscal e a complexidade do sistema tributário e suas alterações na legislação.

Diante de um mercado cada vez mais concorrido, o contador assume um papel importante na gestão tributária, buscando tornar o negócio cada vez mais viável e competitivo. É importante ressaltar que sua figura vai além de um instrumento de arrecadação de tributos, já que se tornou peça fundamental no apoio administrativo e financeiro das empresas. Neste cenário surge a importância do planejamento tributário. De maneira geral, o planejamento tributário é definido como a forma lícita de reduzir à carga fiscal imposta a pessoa jurídica. Segundo Rodrigues (2013, p. 41) "planejamento tributário, nada mais é senão um conjunto de medidas que visam à economia de tributos, de forma legal".

Já na definição Fabretti (2006, p.32) "O estudo feito preventivamente, ou seja, antes da realização do fato administrativo, pesquisando-se seus efeitos jurídicos e econômicos e as alternativas legais menos onerosas, denomina-se Planejamento Tributário, que exige antes de tudo, bom senso do planejador". O Planejamento tributário ajuda a identificar três finalidades básicas, são elas: evitar a incidência do fato gerador do tributo; reduzir o montante do tributo, sua alíquota ou reduzir sua base de cálculo; e retardar o pagamento do tributo, postergando o seu pagamento sem a incidência de multa. 
Rosa, F. C., Mandu, T. O., Grecco, M. C. P., Silva, F. L., Antunes, M. T. P.; Relação entre o Valor Adicionado distribuído e a satisfação dos Funcionários

Quando executado de maneira lícita e de acordo com o que permite o ordenamento jurídico brasileiro, o Planejamento Tributário contribui de maneira significativa para a maximização dos lucros. Oliveira e Gonçalves (2015) explicam o planejamento tributário tende a se tornar uma importante ferramenta para redução de custos e competitividade do mercado.

\subsection{Regimes Tributários}

4.1 O regime de tributação consiste na escolha feita pela pessoa jurídica para que as obrigações tributárias, sejam elas principais ou acessórias, sejam cumpridas em determinado ano-calendário de acordo com a legislação que rege o regime escolhido. Santos e Oliveira (2008) abordam que cada regime de tributação passa a possuir uma legislação específica, onde estás visa determinar todos os métodos a serem seguidos pelas empresas, diante do enquadramento mais viável. Desta forma, de acordo com o regime de tributação optado, o contribuinte deverá recolher determinados tributos com respectivas alíquotas, além de cumprir suas obrigações acessórias de acordo com a lei correspondente ao regime escolhido. Evidencia-se ainda, que o Sistema Tributário Nacional dispõe das seguintes formas de tributação: o Lucro Real, Lucro Presumido, Lucro Arbitrado e Regime Especial Unificado de Arrecadação de Tributos - Simples Nacional.

Conforme Castro et al. (2007, p. 58) “as pessoas jurídicas são tributadas por uma das formas de apuração do IRPJ e da CSLL, por opção do contribuinte ou por determinação legal [...]." Desta forma, pode-se afirmar que a principal diferença entre os regimes de tributação é a forma determinada de recolher o Imposto de Renda Pessoa Jurídica (IRPJ) e a Contribuição Social sobre o Lucro Líquido (CSLL). O contribuinte poderá escolher qual será seu regime de tributação ou estar a obrigado a determinado regime por determinação legal de acordo com os critérios estabelecidos como a atividade desempenhada ou seu faturamento, por exemplo.

Uma maneira de executar o planejamento tributário é através da escolha do regime tributário menos oneroso de acordo com o perfil da empresa, visando, assim, optar pelo regime que possibilite a maior economia tributária conforme o contexto da empresa. A escolha pelo regime de tributação deverá ser minuciosamente estudada pelos administradores, uma vez que está diretamente ligado com a carga tributária suportada pelo contribuinte. Uma vez escolhida à opção mais onerosa para o contribuinte, tal escolha poderá afetar a rentabilidade do negócio ou até mesmo leva-lo a inviabilidade.

\subsubsection{Lucro Real}

Entende-se por Lucro Real o lucro líquido do período apurado mediante o estabelecido pela legislação específica, considerando as devidas exclusões e adições na qual rege a legislação de Imposto de Renda (SILVA e RODRIGUES 2006). Inicialmente a definição de Lucro Real foi introduzida na legislação tributária brasileira através do Decreto-Lei $n^{\circ} 5.844 / 43$. O referido Decreto-Lei tratou das deduções e adições para a apuração do lucro tributável. No entanto, o desmembramento entre o resultado obtido pela contabilidade e a base de cálculo do IRPJ deuse somente com a publicação do Decreto-Lei n ${ }^{\circ}$ 1.598/77, que criou o Livro de Apuração do Lucro Real - LALUR.

Neste regime tributário a base de cálculo IRPJ e da CSLL é apurada segundo os registros contábeis e fiscais efetuados de acordo com as leis comerciais e fiscais. O Lucro Real é apurado na parte A do Livro de Apuração do lucro real - LALUR, mediante adições e exclusões ao 
Rosa, F. C., Mandu, T. O., Grecco, M. C. P., Silva, F. L., Antunes, M. T. P.; Relação entre o Valor Adicionado distribuído e a satisfação dos Funcionários

lucro líquido do período de apuração, seja ela trimestral ou anual, do imposto e compensação de prejuízos fiscais autorizados pela legislação do imposto de renda segundo o disposto na Instrução Normativa SRF $n^{\circ} 281$ de 1978, e demais atos legais e infra legais posteriores (IBPT, 2013).

O Regulamento do Imposto de Renda - RIR/99 define que:

Art. 247. Lucro real é o lucro líquido do período de apuração ajustado pelas adições, exclusões ou compensações prescritas ou autorizadas por este Decreto (Decreto-Lei no 1.598 , de 1977, art. $6^{\circ}$ ).

$\S 1^{\circ}$ A determinação do lucro real será precedida da apuração do lucro líquido de cada período de apuração com observância das disposições das leis comerciais (Lei $\mathrm{n}^{\circ} 8.981$, de 1995, art. 37, § $1^{\circ}$ ).

$\S 2^{\circ}$ Os valores que, por competirem a outro período de apuração, forem, para efeito de determinação do lucro real, adicionados ao lucro líquido do período de apuração, ou dele excluídos, serão, na determinação do lucro real do período de apuração competente, excluídos do lucro líquido ou a ele adicionados, respectivamente, observado o disposto no parágrafo seguinte (Decreto-Lei $\mathrm{n}^{\circ} 1.598$, de 1977 , art. $\left.6^{\circ}, \S 4^{\circ}\right)$.

O referido regulamento define ainda o Lucro Líquido:

Art. 248. O lucro líquido do período de apuração é a soma algébrica do lucro operacional (Capítulo V), dos resultados não operacionais (Capítulo VII), e das participações, e deverá ser determinado com observância dos preceitos da lei comercial (Decreto-Lei ${ }^{\circ} 1.598$, de 1977, art. $6^{\circ}$, $\S 1^{\circ}$, Lei $n^{\circ} 7.450$, de 1985, art. 18, e Lei $n^{\circ} 9.249$, de 1995 , art. $\left.4^{\circ}\right)$.

Art. 274. Ao fim de cada período de incidência do imposto, o contribuinte deverá apurar o lucro líquido mediante a elaboração, com observância das disposições da lei comercial, do balanço patrimonial, da demonstração do resultado do período de apuração e da demonstração de lucros ou prejuízos acumulados (Decreto-Lei $\mathrm{n}^{\circ}$ 1.598, de 1977, art. $7^{\circ}, \S 4^{\circ}$, e Lei ${ }^{\circ} 7.450$, de 1985, art. 18).

$\S 1^{\circ}$ O lucro líquido do período deverá ser apurado com observância das disposições da Lei $\mathrm{n}^{\circ}$ 6.404, de 1976 (Decreto-Lei $\mathrm{n}^{\circ} 1.598$, de 1977, art. 67, inciso XI, Lei $n^{\circ} 7.450$, de 1985, art. 18, e Lei ${ }^{\circ}$ 9.249, de 1995 , art. $\left.5^{\circ}\right)$.

O lucro real, portanto, é à base de cálculo do imposto de renda partindo do resultado apresentado na contabilidade, com os devidos ajustes (CHAVES, 2010, p.03). Desta forma, pode-se definir que o lucro real, em suma, como o lucro fiscal, tendo em vista que a determinação do imposto a pagar pelas pessoas jurídicas é obtida através da base de cálculo que, por vezes, não é idêntica a estabelecida pelas normas contábeis.

Conforme definido no artigo 14 da Lei $\mathrm{n}^{\circ} 9.718$ de 1998, estão obrigadas a optar pelo Lucro Real as pessoas cuja receita total no ano-calendário anterior seja superior ao limite de $\mathrm{R} \$$ 78.000.000,00 (setenta e oito milhões) ou proporcional ao número de meses do período, quando inferior a 12 (doze) meses. 
Rosa, F. C., Mandu, T. O., Grecco, M. C. P., Silva, F. L., Antunes, M. T. P.; Relação entre o Valor Adicionado distribuído e a satisfação dos Funcionários

No entanto, a receita bruta anual não é o único fator que determina à obrigatoriedade de optar pelo Lucro Real, as atividades desempenhadas como: bancos comerciais, bancos de investimentos, bancos de desenvolvimento, caixas econômicas, sociedades de crédito, financiamento e investimento, sociedades de crédito imobiliário, sociedades corretoras de títulos, valores mobiliários e câmbio, distribuidoras de títulos e valores mobiliários ou empresas de arrendamento mercantil também estão obrigadas ao Lucro Real.

\subsubsection{Lucro Presumido}

O Lucro Presumido é uma forma de tributação simplificada para determinação da base de cálculo de Imposto de Renda - IRPJ e da Contribuição Social Sobre o Lucro Líquido - CSLL das pessoas jurídicas que não estiverem obrigadas, no ano-calendário, à apuração do Lucro Real. O lucro é determinado com base na presunção, calculado a partir da incidência sobre a receita bruta, dos percentuais de $1,6 \%, 8 \%, 16 \%$ ou $32 \%$, conforme a atividade geradora. Sobre esse resultado ainda devem ser adicionados, as demais receitas e os ganhos de capital. Nesses termos, apurada a base de cálculo, são aplicadas as alíquotas do IRPJ e da CSLL.

Conforme Young (2008, p.36) "[...] o lucro presumido é o lucro que se presume obtido pela empresa sem escrituração contábil, para efeito do pagamento do imposto de renda, calculado por um coeficiente aplicado sobre a receita bruta". Já Iudícibus et al. (2010. p. 347) abordam que "[...] no caso do lucro presumido, a base de calculo é um percentual fixado sobre o faturamento e ajustado por algumas outras receitas da sociedade. Esse percentual depende da atividade desenvolvida pela empresa".

Conforme define o RIR/99, poderão optar pelo lucro presumido as pessoas jurídicas que:

Art. 516. A pessoa jurídica cuja receita bruta total, no ano-calendário anterior, tenha sido igual ou inferior a vinte e quatro milhões de reais, ou a dois milhões de reais multiplicados pelo número de meses de atividade no ano-calendário anterior, quando inferior a doze meses, poderá optar pelo regime de tributação com base no lucro presumido (Lei no 9.718, de 1998, art. 13).

$\S 1^{\circ}$ A opção pela tributação com base no lucro presumido será definitiva em relação a todo o ano-calendário (Lei no 9.718, de 1998, art. $\left.13, \S 1^{\circ}\right)$.

$\S 2^{\circ}$ Relativamente aos limites estabelecidos neste artigo, a receita bruta auferida no ano anterior será considerada segundo o regime de competência ou caixa, observado o critério adotado pela pessoa jurídica, caso tenha, naquele ano, optado pela tributação com base no lucro presumido (Lei ${ }^{\circ} 9.718$, de 1998, art. 13, $\S 2^{\circ}$ ).

$\S 3^{\circ}$ A pessoa jurídica que não esteja obrigada à tributação pelo lucro real (art. 246), poderá optar pela tributação com base no lucro presumido.

$\S 4^{\circ}$ A opção de que trata este artigo será manifestada com o pagamento da primeira ou única quota do imposto devido correspondente ao primeiro período de apuração de cada ano-calendário (Lei n ${ }^{\circ} 9.430$, de 1996 , art. $26, \S 1^{\circ}$ ). 
Rosa, F. C., Mandu, T. O., Grecco, M. C. P., Silva, F. L., Antunes, M. T. P.; Relação entre o Valor Adicionado distribuído e a satisfação dos Funcionários

$\S 5^{\circ} \mathrm{O}$ imposto com base no lucro presumido será determinado por períodos de apuração trimestrais, encerrados nos dias 31 de março, 30 de junho, 30 de setembro e 31 de dezembro de cada ano-calendário, observado o disposto neste Subtítulo (Lei no 9.430, de 1996, Art's. $1^{\circ}$ e 25$)$.

A opção pelo regime de tributação com base no lucro presumido será manifestada com o pagamento da primeira ou única quota do imposto devido correspondente ao primeiro período de apuração de cada ano-calendário. Já no caso das pessoas jurídicas que iniciarem as atividades a partir do segundo trimestre, a opção será manifestada com o pagamento da primeira ou única quota do imposto devido, relativo ao período de apuração do início de atividade. Ressalta-se que a tributação com base no lucro presumido é uma opção do contribuinte, desde que ele não esteja impedido de aderir a esse regime de tributação.

\subsubsection{Lucro Arbitrado}

O lucro arbitrado, em regra geral, é uma forma de apuração do IRPJ e CSLL utilizado por opção do contribuinte ou por determinação do fisco. A Lei no 8.891/95 em seu art. 47 elenca as possibilidades em que o contribuinte terá o arbitramento do seu lucro. E dentre as possibilidades pode-se destacar a hipóteses em que o contribuinte não mantiver escrituração na forma das leis comerciais e fiscais, ou deixar de elaborar as demonstrações financeiras exigidas pela legislação fiscal. A tributação com base no lucro arbitrado também poderá ser manifestada por opção do contribuinte mediante o pagamento da primeira quota ou da quota única do imposto devido, correspondente ao período de apuração trimestral em que o contribuinte, pelas razões determinantes na legislação, se encontrar em condições de proceder ao arbitramento do seu lucro.

Oliveira et al. (2013) expõem que o lucro arbitrado é utilizado pelo fisco para determinação da base de cálculo do Imposto de Renda da Pessoa Jurídica e da Contribuição Social Sobre o Lucro Líquido devido pelo contribuinte, quando a pessoa jurídica descumprir as obrigações acessórias relativas à determinação do lucro real ou presumido ou se recusar a fornecer os livros e documentos contábeis e fiscais solicitados em um processo de fiscalização.

Quando conhecida a Receita Bruta, os percentuais aplicáveis sobre esta para cálculo do Imposto de Renda Pessoa Jurídica - IRPJ e Contribuição Social Sobre o Lucro Líquido - CSLL são os mesmos utilizados para o cálculo do Lucro Presumido, no entanto, são acrescidos $20 \%$. $\mathrm{Ou}$ seja, as alíquotas aplicáveis ao Lucro Presumido serão multiplicadas por 1,2, consequentemente acarretará um maior ônus tributário ao contribuinte no montante de $20 \%$ quando comparado à tributação com base no Lucro Presumido.

O arbitramento do lucro é aplicado pelo fisco em caráter punitivo. Representa maioria das vezes, maior carga tributária para o contribuinte. Dificilmente as empresas que tem seus registros contábeis e fiscais regulares, e estando de acordo com as leis e normas civis optam por apurar seus tributos mediante o arbitramento do lucro. 
Rosa, F. C., Mandu, T. O., Grecco, M. C. P., Silva, F. L., Antunes, M. T. P.; Relação entre o Valor Adicionado distribuído e a satisfação dos Funcionários

\subsubsection{Simples Nacional}

Inicialmente, o Simples Nacional foi instituído pela Lei Complementar $n^{\circ}$ 9.317/96 que dispôs sobre o regime tributário das Microempresas (ME) e das Empresas de Pequeno Porte (EPP), instituindo o Sistema Integrado de Pagamento de Impostos e Contribuições das Microempresas e das Empresas de Pequeno Porte - SIMPLES, ficando popularmente conhecido como Simples Federal. No entanto, esta lei foi revogada pela Lei Complementar $\mathbf{N}^{\circ}$ 123/06. Esta instituiu o Sistema Integrado de Pagamento de Impostos e Contribuições das Microempresas e Empresas de Pequeno Porte (SIMPLES NACIONAL) entrando em vigor a partir de $1^{\circ}$ de julho de 2007. Em seguida, com a edição da Lei Complementar $n^{\circ}$ 128/08, o referido sistema foi estendido aos Microempreendedores Individuais (MEI). A última alteração no Simples Nacional se deu pela Lei Complementar ${ }^{\circ}$ 155/16.

De acordo com a Receita Federal (2018), o Simples Nacional é um regime compartilhado de arrecadação, cobrança e fiscalização de tributos aplicável às Microempresas e Empresas de Pequeno Porte, previsto na Lei Complementar $\mathrm{n}^{\circ}$ 123, de 14 de dezembro de 2006. Para efeitos da Lei complementar $\mathrm{n}^{\circ} 123 / 06$, considera-se microempresas (ME) aquelas cuja receita bruta anual é igual ou inferior a $\mathrm{R} \$ 360.000,00$. Já as empresas de pequeno porte (EPP) são aquelas que cuja receita bruta anual é superior a $\mathrm{R} \$ 360.000,00$ e igual ou inferior a $\mathrm{R} \$ 4.800 .000,00$.

Conforme Young (2009), “o Simples Nacional é uma forma de tributação que podemos considerar como progressiva, ou seja: à medida do aumento do faturamento, muda-se a alíquota da tributação". Este regime resume-se no recolhimento único de impostos e contribuições baseado numa tabela progressiva aplicada sobre o faturamento da empresa.

Podem-se destacar como principais objetivos do simples nacional o de: integrar o fisco federal, estadual e municipal; melhorar o ambiente de negócios do país; racionalizar procedimentos para o fisco e para as empresas; unificar o recolhimento de tributos em nível federal, estadual e municipal; facilitar o cumprimento das obrigações tributárias; reduzir a carga tributária e diminuir a informalidade e incentivar a formação de novas empresas.

Poderá optar pelo Simples Nacional as pessoas jurídicas que atenderem os requisitos disposto na Lei Complementar 123/06, a referida lei define em seu art. 3 que poderão optar pelo simples nacional as pessoas jurídicas:

I - no caso da microempresa aufira, em cada ano-calendário, receita bruta igual ou inferior a $\mathrm{R} \$ 360.000,00$ (trezentos e sessenta mil reais); e

II- empresa de pequeno porte a pessoa jurídica que tenha auferido no ano calendário, receita bruta superior a $\mathrm{R} \$ 360.000,00$ (trezentos e sessenta mil reais) e igual ou inferior a $\mathrm{R} \$ 4.800 .000,00$ (Quatro milhões e oitocentos mil reais).

Além da receita bruta anual, existem outros requisitos que devem ser atendidos para ingresso ao regime do Simples Nacional. Conforme os artigos $3^{\circ}$ e $17^{\circ}$ da Lei Complementar $n^{\circ}$ 123/06, algumas atividades e situação vedam o ingresso ao Simples Nacional. Podemos destacar como vedação ao ingresso no Regime do Simples Nacional as microempresas (ME) e empresas de pequeno porte (EPP) que: tenha sócio domiciliado no exterior; cujo capital participe entidade da administração pública, direta ou indireta, federal, estadual ou municipal; 
Rosa, F. C., Mandu, T. O., Grecco, M. C. P., Silva, F. L., Antunes, M. T. P.; Relação entre o Valor Adicionado distribuído e a satisfação dos Funcionários

esteja obrigada a usar o Lucro Real como regime de apuração; cujo capital participe outra pessoa jurídica; etc.

\subsubsection{Tributos Abrangidos Pelo Simples Nacional}

A tributação das empresas optantes pelo Regime Simples Nacional é determinada mediante aplicação das alíquotas efetivas sobre a Receita Bruta conforme a atividade desempenhada. O artigo 18 da Lei Complementar 123/06 traz em anexo cinco tabelas com faixas de tributação de acordo com atividade desenvolvida pelo contribuinte. Por exemplo, o contribuinte que auferir receitas decorrentes da exploração da atividade de revenda de mercadorias adquiridas de terceiras será tributado de acordo com o anexo I da referida Lei Complementar. Já no caso do contribuinte que preste serviço contábil, por exemplo, será tributado conforme o anexo III da Lei Complementar citada. Ressalta-se ainda que, o contribuinte que tenha receitas decorrentes da exploração de mais de uma atividade econômica, deverá segrega-las, para fins de apuração e pagamento do tributo devido de acordo com cada atividade explorada e sua respectiva faixa de tributação.

No artigo 13 a Lei Complementar $n^{\circ}$ 123/06 define que o optante pelo regime de tributação Simples Nacional recolherá, mediante documento único de arrecadação, os seguintes tributos:

a) Imposto sobre a Renda da Pessoa Jurídica - IRPJ;

b) Imposto sobre Produtos Industrializados - IPI;

c) Contribuição Social sobre o Lucro Líquido - CSLL;

d) Contribuição para o Financiamento da Seguridade Social - COFINS, observado o disposto no inciso XII do $\S 1$ o deste artigo;

e) Contribuição para o PIS/Pasep;

f) Contribuição Patronal Previdenciária - CPP para a Seguridade Social, a cargo da pessoa jurídica;

g) Imposto sobre Operações Relativas à Circulação de Mercadorias e Sobre Prestações de Serviços de Transporte Interestadual e Intermunicipal e de Comunicação - ICMS;

h) Imposto sobre Serviços de Qualquer Natureza - ISS.

Conforme destacado por Gabriel (2012), o recolhimento dos tributos previsto pelo Simples Nacional conforme documento único não exclui o contribuinte da contribuição de forma separada de outros tributos, tais como: Imposto sobre Operações de Crédito, Câmbio e Seguro, ou Relativas a Títulos ou Valores Mobiliários - IOF; Imposto sobre a Importação de Produtos Estrangeiros - II; Imposto sobre a Exportação, para o Exterior, de Produtos Nacionais ou Nacionalizados - IE; Imposto sobre a Propriedade Territorial Rural - ITR; Contribuição para o Fundo de Garantia do Tempo de Serviço - FGTS; e demais tributos que não estejam abrangidos pelo artigo 18 da Lei Complementar ${ }^{\circ}$ 123/06. 
Rosa, F. C., Mandu, T. O., Grecco, M. C. P., Silva, F. L., Antunes, M. T. P.; Relação entre o Valor Adicionado distribuído e a satisfação dos Funcionários

\subsubsection{Alterações do Simples Nacional}

A primeira alteração na Lei Complementar no 123/06 deu-se através da publicação da Lei Complementar $n^{\circ} 127 / 07$, a qual ampliou as atividades permitidas pelo Simples Nacional, mais especificamente as atividades de prestação de serviços. A referida lei também alterou a forma de apuração da Contribuição para a Seguridade Social passa a chamar-se Contribuição Patronal Previdenciária - CPP de algumas atividades de prestação de serviço.

No ano seguinte, a Lei Complementar $n^{\circ}$ 123/06 foi novamente alterada, desta vez pela Lei Complementar $n^{\circ} 128 / 08$. Dentre as alterações trazidas pela referida lei pode-se destacar a criação da figura do Microempreendedor Individual (MEI) e sua inclusão no ao regime de tributação pelo Simples Nacional. O MEI foi definido como o empresário individual cujo faturamento é de até R\$ 60.000,00 no ano.

Em 2014, o Simples Nacional sofre outra alteração, na qual suas regras foram ampliadas por força da Lei Complementar $\mathrm{n}^{\circ}$ 147/14. Pode-se destacar como uma das principais mudanças à inclusão de novas atividades que antes eram vedadas o ingresso ao regime de tributação Simples Nacional e a criação do Anexo VI. Por exemplo, a inclusão da atividade de Fonoaudiologia e seu enquadramento no anexo VI do Simples Nacional.

Já no ano de 2016, a Lei Complementar no 155/16 trouxe novas regras ao Simples Nacional. Os limites da receita bruta anual foram ampliados e a partir de $1^{\circ}$ de janeiro de 2018 o Microempreendedor Individual (MEI) passa de um limite anual de R \$ 60.000,00para R \$ $81.000,00$ por ano, uma média mensal de $\mathrm{R} \$ 6.750,00$, e a Empresa de Pequeno Porte (EPP) passa de $\mathrm{R} \$ 3.600 .000,00$ para $\mathrm{R} \$ 4.800 .000,00$ anuais, com média mensal de $\mathrm{R} \$ 400.000,00$.

A lei reduziu ainda as tabelas que passaram de 6 para 5 (uma para comércio, uma para indústria e três para os serviços). O número de faixas e alíquotas aplicadas sobre o faturamento também caiu de 20 para 6 . A nova redação também permutou algumas atividades entre as tabelas. $\mathrm{O}$ anexo VI foi extinto e as atividades enquadradas neste anexo passaram a ser tributadas no anexo III ou pelo novo anexo V. Por exemplo, a atividade de fonoaudiologia que antes das alterações trazidas pela $\mathrm{LC}^{\circ}{ }^{\circ} 155 / 16$ era tributada de acordo com o anexo VI com alíquota inicial de $16,93 \%$, a partir de $1^{\circ}$ de janeiro de 2018 passou a ser enquadrada no Anexo $\mathrm{V}$, com alíquota inicial de $15,50 \%$. No entanto, a tributação da atividade de Fonoaudiologia poderá, ainda, ser tributada conforme o anexo III. A tributação será de acordo com anexo III, caso o "Fator R" seja igual ou superior a 0,28 ou $28 \%$. O Fator R consiste na divisão da massa salarial (salários, encargos, pró-labore) pelo faturamento nos últimos 12 meses. Ou seja, corresponde a porcentagem do faturamento destinada a gostos com folha de pagamento. Isto é, uma medida do nível de utilização de mão de obra.

Outra alteração importante trazida pela Lei Complementar $\mathrm{n}^{\circ} 155 / 16$ foi à forma como é calculado o tributo mensal a ser recolhido pelo optante do regime de tributação Simples Nacional. Anteriormente as alterações trazidas pela LC $n^{\circ} 155 / 16$, para apuração do tributo mensal a ser recolhido, o contribuinte só necessitava de duas informações: Receita bruta total nos doze meses anteriores ao mês de apuração e a Receita bruta total do mês de apuração. De posse da primeira informação o contribuinte descobria a alíquota a ser utilizada para apurar os tributos mensais mediante as tabelas em anexo à Lei. Com a obtenção da alíquota, era necessário, apenas, aplicá-la sobre a receita bruta do mês e, permitindo assim, a descoberta a carga tributária do mês de apuração.

Com a alteração, aparecem então as figuras da Alíquota Efetiva e da Parcela a Deduzir (PD). A alíquota a ser paga dependerá de um cálculo que leva em consideração a Receita Bruta 
Rosa, F. C., Mandu, T. O., Grecco, M. C. P., Silva, F. L., Antunes, M. T. P.; Relação entre o Valor Adicionado distribuído e a satisfação dos Funcionários

Acumulada nos doze meses anteriores (RBT12) ao mês de Apuração e, de posse da RBT12, o contribuinte descobre sua Alíquota Nominal mediante as tabelas dos Anexos I a V da LC n ${ }^{\circ}$ 155/16. Entretanto, com a Alíquota Nominal, é preciso descobrir a Alíquota Efetiva. O cálculo para obtenção da Alíquota Efetiva é dado pela seguinte equação:

$$
\text { Alíquota Efetiva }=\frac{(\text { RBT12 } x \text { Alíquota Nominal })-P D}{R B T 12}
$$

Onde:

i. $\quad$ RBT12: Receita Bruta Acumulada nos últimos doze meses;

ii. Alíquota Nominal: alíquota nominal constante dos Anexos I a V da LC n ${ }^{\circ} 155 / 16$;

iii. PD: parcela a deduzir constante dos Anexos I a V desta Lei Complementar.

4.2 Com base no resultado da seguinte equação encontra-se, então, a Alíquota Efetiva. O valor devido mensalmente pela Microempresa ou Empresa de Pequeno Porte optante pelo Simples Nacional será obtido mediante aplicação da Alíquota Efetiva à Receita Bruta do mês de apuração.

\section{Procedimentos Metodológicos}

O presente trabalho tem como objetivo analisar a melhor maneira para um empresário individual com atuação na prestação de serviço de fonoaudiologia, localizado na cidade de Mossoró/RN apurar seus tributos. Para tanto foi realizado um estudo de caso, Raupp e Beuren (2013) definem o estudo caso como aquele concentrado em um único caso, comumente utilizado por pesquisadores que desejam aprofundar seus conhecimentos a respeito de determinado caso específico. A empresa de fonoaudiologia estudada iniciou suas atividades em julho de 2015, estando há pouco mais de três anos em atividade. No período pesquisado, a empresa esteve enquadrada como microempresa e optante pelo Simples Nacional como regime para o recolhimento dos tributos e cumprimento das suas obrigações acessórias, e não apresentou durante este período registro de funcionários. Dessa forma, todos os gastos com folha de pagamento são relativos à remuneração a título de pró-labore e indexado de acordo com o salário mínimo.

O presente estudo limitou-se a analisar o comportamento da empresa diante de dois dos quatros regimes de tributação brasileira. Dessa forma, os dados foram analisados sob a ótica do regime de tributação Lucros Presumido e Simples Nacional. Evidencia-se que, o regime tributário pelo Lucro Real foi desconsiderado, uma vez que, a empresa estudada não mantém a contabilidade de forma regular e, desta forma, impossibilitou os cálculos para apuração dos tributos conforme o regime mencionado. Excluiu-se também o Lucro Arbitrando por ser tratar da mesma sistemática que o Lucro Presumido, sendo este acrescido de 20\%, usualmente utilizado pelo fisco como forma de punição aos contribuintes que descumpriram obrigações acessórias relativas à determinação do Lucro Real ou Presumido ou, ainda, se recusou a fornecer os livros fiscais e documentos contábeis e fiscais solicitados em processo de fiscalização.

Analisou-se, então, a carga tributária incidente sobre a Receita Bruta da empresa de acordo com a Lei Complementar $n^{\circ}$ 123/06 (válida até 31/12/2017) e, também, a carga tributária após as alterações realizadas pela Lei Complementar $n^{\circ} 155 / 16$, a qual entrou em vigor a partir de 01 de janeiro 2018. Comparou-se, também, o regime tributário Simples Nacional e suas alterações com o regime tributário Lucro presumido no intuito de verificar o menos oneroso. 
Rosa, F. C., Mandu, T. O., Grecco, M. C. P., Silva, F. L., Antunes, M. T. P.; Relação entre o Valor Adicionado distribuído e a satisfação dos Funcionários

Para atender a forma de abordagem do problema, a presente pesquisa foi caracterizada como qualitativa. Segundo Vieira e Zouain (2004), o método qualitativo assegura dados mais fidedignos, uma vez que permite visualizar um fenômeno como um todo, facilitando a exploração de controvérsias e paradoxos. A pesquisa buscou descrever os regimes tributários focando nas alterações realizadas pela $\operatorname{LC} n^{\circ}$ 155/16. Para Andrade (2002) a pesquisa descritiva preocupa-se em observar os fatos, registrá-los, analisa-los, classificá-los e interpretá-los, e o pesquisador não interfere neles.

Em relação aos procedimentos técnicos, a pesquisa classificou-se como documental por meio da utilização de dados primários. Marconi e Lakatos (2002) definiram que, a pesquisa documental é caracterizada pela coleta de dados restritos a documentos, escritos ou não, constituindo o que se denomina de fontes primárias. Evidencia-se que, os dados foram obtidos através de documentos e arquivos privados fornecidos pela empresa bem como por seu contador, contendo o tipo jurídico, regime de tributação, relatório de faturamento dos meses entre 07/2017 a 06/2018, folhas de salários do mesmo período, livros contábeis e o extrato apuração do Simples Nacional. Destaca-se ainda que, os seis meses compreendidos no ano de 2017 foram selecionados para análise devido sua tributação ter como base a LC n ${ }^{\circ}$ 123/06 e igual número de meses analisados em 2018. Foram analisados os seis primeiros meses de apuração de 2018, uma vez que estes eram os períodos disponíveis na data da pesquisa, bem como sua tributação ser baseada nas alterações realizadas pela LC n 155/16.

Para determinação do Lucro Presumido foram utilizados os percentuais de presunção previstos no Decreto $\mathrm{n}^{\circ}$ 3.000/99. O mesmo define o percentual de presunção equivalente a 32\% da receita bruta para a determinação da base de cálculo do IRPJ das atividades de serviços em geral, bem como as atividades regulamentadas de caráter intelectual, a qual se encaixa a empresa estudada. O percentual de presunção da CSLL para determinação da base cálculo da contribuição segue a mesma regra de presunção do IRPJ, conforme definido na Lei $n^{\circ}$ 8.981/95. O quadro 01 resume os tributos e suas respectivas alíquotas incidentes no regime de tributação Lucro Presumido:

Quadro 01 - Alíquotas do Lucro Presumido para apuração dos tributos.

\begin{tabular}{|c|c|c|c|c|c|}
\hline Regime Tributário & \multicolumn{5}{|c|}{ Tributos } \\
\hline \multirow{2}{*}{ Lucro Presumido } & PIS & COFINS & IRPJ & CSLL & ISS \\
\cline { 2 - 7 } & $0,65 \%$ & $3 \%$ & $15 \%$ & $9 \%$ & $5 \%$ \\
\hline
\end{tabular}

Fonte: De acordo com o D. $n^{\circ} 3.000 / 99$, Lei no $8.981 / 95$ e LC n ${ }^{\circ}$ 096/13.

Considerando que a empresa estudada não excedeu o limite mensal de $\mathrm{R} \$ 20.000,00$ (vinte mil reais) ou $\mathrm{R} \$ 60.000,00$ (sessenta mil reais) por trimestre do seu Lucro Presumido para apuração do adicional de $10 \%$ do IRPJ, conforme previsto no Decreto $\mathrm{n}^{\circ}$ 3.000/99, adotou-se a alíquota direta e, assim, determinar o percentual sobre a receita bruta e apuração do valor a recolher a título de IRPJ e CSLL. A obtenção da alíquota direta se deu através da multiplicação do percentual de presunção multiplicado pelas alíquotas do IRPJ e CSLL que são de 15\% e 9\%, respectivamente. Portanto, tem-se: IRPJ $(32 \%$ x 15\%) =4,8\%; CSLL $(32 \% \times 9 \%)=2,88 \%$.

O Fator R, o qual teve sua fórmula de cálculo e aplicação alterada pela LC $\mathrm{n}^{\circ}$ 155/16, tornando-se peça fundamental na definição entre o anexo V ou III a ser utilizado pelo contribuinte prestador de serviço e optante pelo Simples Nacional na obtenção do valor dos tributos a ser recolhido. Para tanto, o fator R passa a ser determinado a partir da soma de todas as despesas com folha de pagamento e encargos dos últimos doze meses anterior ao período de apuração, dividido pelo faturamento dos últimos doze meses, conforme equação abaixo: 
Rosa, F. C., Mandu, T. O., Grecco, M. C. P., Silva, F. L., Antunes, M. T. P.; Relação entre o Valor Adicionado distribuído e a satisfação dos Funcionários

$$
\text { Fator } \mathrm{R}=\frac{F P 12}{R B T 12}
$$

Onde:

i. $\quad$ FP12: Folha de Pagamento e Encargos dos últimos doze meses;

ii. $\quad$ RBT12: Receita Bruta Acumulada nos doze últimos doze meses.

A partir da análise da carga tributária devida no período analisado conforme os regimes tributários Simples Nacional e Lucro Presumido é possível verificar qual regime de tributação traz maiores benefícios para a empresa. Mediante a isto, após a coleta dos dados, os mesmos foram analisados e posteriormente organizados em quadros e tabelas para melhor visualização e interpretação.

\section{Resultados e Discussões}

Para melhor visualização das principais mudanças decorrentes da publicação da LC $\mathrm{n}^{\circ}$ $155 / 16$, foi elaborado o quadro 2. Abordando assim, as principais alterações nas regras estabelecidas antes e depois $\mathrm{LC} \mathrm{n}^{\circ} 155 / 16$ i entrar em vigor.

Quadro 02 - Principais mudanças a partir da LC no $155 / 06$

\begin{tabular}{|c|c|c|}
\hline Mudanças & LC n⿳ 123/06 & LC no 155/16 \\
\hline Receita Bruta (faturamento) & $\begin{array}{l}\text { Microempreendedor Individual } \\
\text { (MEI): Receita Bruta Anual até R\$ } \\
60.000,00 ; \text { Microempresa (ME): } \\
\text { Receita Brutal Anual até R\$ } \\
\text { 360.000,00; Empresa de Pequeno } \\
\text { Porte (EPP): Receita Bruta Anual até } \\
\text { R\$ 3.600.000,00 }\end{array}$ & $\begin{array}{l}\text { Microempreendedor Individual } \\
\text { (MEI): Receita Bruta Anual até R\$ } \\
\text { 81.000,00; Microempresa (ME): } \\
\text { Receita Brutal Anual até R\$ } \\
\text { 3.600.000,00; Empresa de } \\
\text { Pequeno Porte (EPP): Receita } \\
\text { Bruta Anual até R } \$ 4.800 .000,00\end{array}$ \\
\hline Número Tabelas (anexos) & 6 & 5 \\
\hline Número de Faixas & 20 & 6 \\
\hline Forma de Cálculo & $\begin{array}{l}\text { Alíquota Nominal x Receita Bruta do } \\
\text { mês de referência. }\end{array}$ & $\begin{array}{l}\text { Alíquota Efetiva }=(\text { RBT12 x } \\
\text { Alíquota Nominal })- \text { PD / RBT12 }\end{array}$ \\
\hline Fator $\mathbf{R}$ & $\begin{array}{l}\text { Previsto apenas para determinação } \\
\text { do percentual recolhido a titulo de } \\
\text { Contribuição Previdenciário Patronal } \\
\text { - CPP }\end{array}$ & $\begin{array}{l}\text { Seu índice determina a tributação } \\
\text { de algumas atividades entre o } \\
\text { Anexo III ou Anexo V }\end{array}$ \\
\hline
\end{tabular}

Fonte: Adaptado de acordo com as LC n ${ }^{\circ} 123 / 06$ e LC n ${ }^{\circ}$ 155/16.

Destaca-se dentre elas, a nova formula de cálculo para obtenção da alíquota a ser utilizada pelo contribuinte. Anterior da LC $n^{\circ} 155 / 06$, para saber qual alíquota utilizar e obter o valor mensal dos tributos a serem pagos, o contribuinte, mediante sua receita bruta acumulada nos doze meses anterior ao mês de apuração, encontrava sua faixa de tributação e aplicava a alíquota nela prevista.

No entanto, a partir da vigência da $L C \mathrm{n}^{\circ}$ 155/16, a alíquota a ser utilizada para determinação do valor mensal dos tributos a ser recolhido, depende de um cálculo que leva em consideração a receita bruta acumulada nos últimos dozes meses e o desconto fixo. O resultado deste novo cálculo foi determinado de alíquota efetiva. A alíquota agora se torna variável, à medida que o faturamento da empresa varia sua alíquota mensal também varia para mais ou para menos. Antes da lei $\mathrm{LC}^{\circ} 155 / 16$, a alíquota era fixa por faixa de faturamento.

Outra mudança importante foi o aumento dos limites anuais de faturamento para o Simples Nacional. O novo limite para enquadramento no Simples, que antes era das alterações oriundas da $\operatorname{LC} n^{\circ} 155 / 16$ era de $\mathrm{R} \$ 3.600 .000,00$, foi majorado para $\mathrm{R} \$ 4.800 .000,00$ a partir de $1^{\circ}$ de 
Rosa, F. C., Mandu, T. O., Grecco, M. C. P., Silva, F. L., Antunes, M. T. P.; Relação entre o Valor Adicionado distribuído e a satisfação dos Funcionários

janeiro de 2018. No entanto, a LC n⿳155/16 determinou também que, as empresas que ultrapassarem o limite de $\mathrm{R} \$ 3.600 .000,00$ no ano de 2017 ainda poderão permanecer no Simples Nacional no ano de 2018, no entanto, os valores recolhidos a título de ICMS e ISS não serão mais de acordo com as regras do Simples Nacional e sim, conforme determinar as legislações dos Estados e Municípios para recolhimento dos respectivos tributos.

\subsection{SIMPLES NACIONAL DE ACORDO COM A LC Nº 123/06}

A Lei Complementar $n^{\circ} 123 / 06$, a qual instituiu o Simples Nacional, trouxe inicialmente cinco anexos com tabelas, cada uma contendo 20 faixas de receita bruta anual, conforme visto no quadro 2, que indicam as alíquotas a serem utilizadas na apuração dos tributos devidos mensalmente abrangidos pelo Simples Nacional. Conforme Filho (2010), o Simples Nacional consiste em uma forma simplificada e unificada de recolhimentos de tributos, por meio da aplicação de percentuais previstos e favorecidos, incidentes sobre uma única base de cálculo, a receita bruta.

As alíquotas de cada tabela e anexo variam de acordo com a receita bruta acumulada nos últimos doze meses auferida pelo contribuinte. Inicialmente, para cálculo do Simples Nacional, deve-se identificar o anexo no qual a empresa se encaixa. A atividade de Fonoaudiologia foi incluída no Simples Nacional com publicação de LC n $^{\circ}$ 147/14 e sua produção de efeito a partir de $1^{\circ}$ janeiro de 2015, em seu anexo VI. A Tabela 1 mostra quanto pagou de tributos à empresa objeto do estudo de acordo com a LC n ${ }^{\circ}$ 123/06 entre os meses de julho de 2017 a dezembro de 2017, estes sendo os últimos seis meses das regras vigentes na LC $\mathrm{n}^{\mathrm{o}} 123 / 06$ antes das alterações realizadas pela $\mathrm{LC} \mathrm{n}^{\mathrm{o}} 155 / 16$.

Tabela 1 - Simples Nacional de acordo com a LC 123/06

\begin{tabular}{c|c|c|c}
\hline MÊS-ANO & RECEITA BRUTA & ALÍQUOTA & TRIBUTOS \\
\hline jul/17 & $\mathrm{R} \$ 9.812,00$ & $16,93 \%$ & $\mathrm{R} \$ 1.661,17$ \\
\hline $\mathrm{ago} / 17$ & $\mathrm{R} \$ 12.006,00$ & $16,93 \%$ & $\mathrm{R} \$ 2.032,62$ \\
\hline set/17 & $\mathrm{R} \$ 10.816,00$ & $16,93 \%$ & $\mathrm{R} \$ 1.831,15$ \\
\hline out $/ 17$ & $\mathrm{R} \$ 16.006,00$ & $16,93 \%$ & $\mathrm{R} \$ 2.709,82$ \\
\hline nov/17 & $\mathrm{R} \$ 0,00$ & $16,93 \%$ & $\mathrm{R} \$ 0,00$ \\
\hline dez/17 & $\mathrm{R} \$ 8.882,00$ & $16,93 \%$ & $\mathrm{R} \$ 1.503,72$ \\
\hline TOTAL & $\mathbf{R} \$ \mathbf{5 7 . 5 2 2 , 0 0}$ & TOTAL & $\mathbf{R} \$ \mathbf{9 . 7 3 8 , 4 7}$ \\
\hline
\end{tabular}

Fonte: Dados da pesquisa (2018)

A empresa esteve enquadrada na primeira faixa do anexo VI, uma vez que esta comporta os contribuintes que auferiram receita bruta anual igual ou inferior a $\mathrm{R} \$ 180.000,00$. Tal faixa tem alíquota inicial de $16,93 \%$. O montante de tributos recolhido no período foi de $\mathrm{R} \$ 9.738,47$. Já o faturamento do semestre totalizou $\mathrm{R} \$ 57.522,00$, uma média mensal de faturamento de $\mathrm{R} \$$ $9.587,00$. 
Rosa, F. C., Mandu, T. O., Grecco, M. C. P., Silva, F. L., Antunes, M. T. P.; Relação entre o Valor Adicionado distribuído e a satisfação dos Funcionários

\subsection{Simples Nacional de acordo com a $\operatorname{LC} \mathrm{n}^{0} \mathbf{1 5 5 / 1 6}$}

A tabela 2 mostra a quanto à empresa pagou de tributos de acordo com a LC $n^{\circ}$ 155/16. Com a referida lei em vigor, a partir de janeiro de 2018, a atividade de Fonoaudiologia sai do anexo VI e passar a ser tributada conforme o anexo III ou V. A tributação será determinada entre o anexo III ou V mediante o percentual do Fator R. Ou seja, caso o Fator R seja igual ou superior 0,28 ou $28 \%$, a tributação será de acordo com o anexo III, no contrário, será tributada conforme o anexo V. Com Fator R inferior a 28\%, a tributação da empresa deu-se de acordo com o anexo $\mathrm{V}$.

Tabela 2 - Simples Nacional de acordo com a LC 155/16

\begin{tabular}{c|c|c|c}
\hline MÊS-ANO & RECEITA BRUTA & ALÍQUOTA & TRIBUTOS \\
\hline jan/18 & $\mathrm{R} \$ 3.648,00$ & $15,50 \%$ & $\mathrm{R} \$ 565,44$ \\
\hline $\mathrm{fev} / 18$ & $\mathrm{R} \$ 0,00$ & $15,50 \%$ & $\mathrm{R} \$ 0,00$ \\
\hline $\mathrm{mar} / 18$ & $\mathrm{R} \$ 2.800,00$ & $15,50 \%$ & $\mathrm{R} \$ 434,00$ \\
\hline $\mathrm{abr} / 18$ & $\mathrm{R} \$ 6.510,00$ & $15,50 \%$ & $\mathrm{R} \$ 1.009,05$ \\
\hline $\mathrm{mai} / 18$ & $\mathrm{R} \$ 3.892,00$ & $15,50 \%$ & $\mathrm{R} \$ 603,26$ \\
\hline jun/18 & $\mathrm{R} \$ 5.801,25$ & $15,50 \%$ & $\mathrm{R} \$ 899,19$ \\
\hline TOTAL & $\mathrm{R} \$ \mathbf{2 2 . 6 5 1 , 2 5}$ & TOTAL & $\mathbf{R} \mathbf{3 . 5 1 0 , 9 4}$ \\
\hline
\end{tabular}

Fonte: Dados da pesquisa (2018)

Com a LC $n^{\circ} 155 / 16$ em vigor a partir de $1^{\circ}$ de janeiro de 2018, logo de início ocorreu uma redução da carga tributária da empresa. Isso pode ser justificado porque o anexo $\mathrm{V}$ tem alíquota inicial fixada em $15,50 \%$. A alíquota inicial prevista no extinto anexo VI era de $16,93 \%$. Com isso, para o ano de 2018 houve uma redução de $1,43 \%$ na alíquota utilizada pela empresa para apuração dos seus tributos. $\mathrm{O}$ monte de tributos recolhido no primeiro semestre de 2018 foi de $R \$ 3.510,94$, um total de $R \$ 6.227,53$ de tributos recolhidos a menos que o segundo semestre de 2017. No entanto, tal redução se deve a diminuição do faturamento. No primeiro semestre de 2018 a média de faturamento foi de $\mathrm{R} \$ 3.775,20$, o que representado aproximadamente uma diminuição de $60 \%$ em relação ao semestre anterior.

\subsection{Lucro Presumido no ano de 2017}

O lucro presumido pode ser entendido como uma forma de tributação e, também, como a base de cálculo utilizada para apuração do Imposto de Renda devido pelo contribuinte que optar por essa forma de tributação (FILHO, 2010). A tabela 3 foi elabora de acordo com o a legislação vigente que regem os tributos e percentuais abrangidos pelo Lucro Presumido. Tais legislações determinam as alíquotas que o contribuinte prestador de serviço de Fonoaudiologia deve utilizar para determinação do valor a recolher de cada tributo de acordo com Lucro Presumido. A tabela demonstra, ainda, o valor total pago de encargos sobre a folha de pagamento.

Tabela 3 - Lucro presumido empresa de serviços $3^{\circ}$ e $4^{\circ}$ trimestre de 2017

\begin{tabular}{c|c|c|c|c}
\hline \multirow{2}{*}{ MÊS-ANO } & \multirow{2}{*}{ RECEITA BRUTA } & \multicolumn{3}{|c}{ LUCRO PRESUMIDO } \\
\cline { 3 - 5 } & $\mathrm{R} \$ 9.812,00$ & ALÍQUOTA & TRIBUTOS & INSS (26,8\%) \\
\hline $\mathrm{jul} / 17$ & $\mathrm{R} \$ 12.006,00$ & $16,33 \%$ & $\mathrm{R} \$ 1.602,30$ & $\mathrm{R} \$ 502,23$ \\
\hline $\mathrm{ago} / 17$ & $\mathrm{R} \$ 10.816,00$ & $16,33 \%$ & $\mathrm{R} \$ 1.960,58$ & $\mathrm{R} \$ 502,23$ \\
\hline $\mathrm{set} / 17$ & $\mathrm{R} \$ 16.006,00$ & $16,33 \%$ & $\mathrm{R} \$ 2.613,78$ & $\mathrm{R} \$ 502,23$ \\
\hline out/17 & $\mathrm{R} \$ 0,00$ & $16,33 \%$ & $\mathrm{R} \$ 0,00$ & $\mathrm{R} \$ 502,23$ \\
\hline nov/17 & \multicolumn{3}{c}{ Redeca, v.6, n.2. Jul-Dez. 2019 p. 103-127. }
\end{tabular}


Rosa, F. C., Mandu, T. O., Grecco, M. C. P., Silva, F. L., Antunes, M. T. P.; Relação entre o Valor Adicionado distribuído e a satisfação dos Funcionários

\begin{tabular}{c|c|c|c|c}
\hline dez $/ 17$ & $\mathrm{R} \$ 8.882,00$ & $16,33 \%$ & $\mathrm{R} \$ 1.450,43$ & $\mathrm{R} \$ 502,23$ \\
\hline TOTAL & $\mathbf{R} \$ \mathbf{5 7 . 5 2 2 , 0 0}$ & TOTAL & $\mathbf{R} \mathbf{9 . 3 9 3 , 3 4}$ & $\mathbf{R} \mathbf{3 . 0 1 3 , 3 8}$ \\
\hline
\end{tabular}

Fonte: Dados da pesquisa (2018)

No segundo semestre de 2017, o total de tributos a ser recolhido conforme o regime tributário Lucro Presumido, levando em consideração somente os tributos incidentes sobre a receita de prestação de serviço, seria de $\mathrm{R} \$ 9.393,34$. Tal valor equivale a um percentual total de $16,33 \%$ incidente sobre a receita bruta de prestação de serviço. Já o total de encargos sobre as a folha de pagamento seria de $\mathrm{R} \$ 3.013,38$, com um percentual de $26,8 \%$ de encargos incidentes sobre a folha de pagamento. O percentual de $26,8 \%$ equivale a: $20 \%$ a titulo de Contribuição Previdenciária Patronal, 5,8 de Outras Entidades e 1\% de RAT ajustada.

O valor pago de encargos sobre a folha de pagamento é o mesmo para todos os meses do segundo semestre de 2017. Tal fato ocorre devido às remunerações pagas serem relativo a pró-labore e indexados em dois salários mínimos vigentes à época. Desta forma, o valor total de tributos a ser pago pela empresa, considerando tanto os tributos sobre a receita de prestação de serviço, bem como os encargos sobre a folha de pagamento, seria de $\mathrm{R} \$ 12.406,72$.

\subsection{Lucro Presumido no ano de 2018}

Da mesma forma que no tópico anterior, o valor que seria pago caso o contribuinte optasse pelo regime tributário Lucro Presumido no ano de 2018, também foi calculado. Os valores estão expressos conforme a tabela 4 :

Tabela 4 - Lucro presumido empresa de serviços $1^{\circ}$ e $2^{\circ}$ trimestre de 2018

\begin{tabular}{c|c|c|c|c}
\hline \multirow{2}{*}{ MÊS-ANO } & \multirow{2}{*}{ RECEITA BRUTA } & \multicolumn{3}{|c}{ LUCRO PRESUMIDO } \\
\cline { 3 - 5 } & & ALÍQUOTA & TRIBUTOS & INSS (26,8\%) \\
\hline jan/18 & $\mathrm{R} \$ 3.648,00$ & $16,33 \%$ & $\mathrm{R} \$ 595,72$ & $\mathrm{R} \$ 511,34$ \\
\hline $\mathrm{fev} / 18$ & $\mathrm{R} \$ 0,00$ & $16,33 \%$ & $\mathrm{R} \$ 0,00$ & $\mathrm{R} \$ 511,34$ \\
\hline $\mathrm{mar} / 18$ & $\mathrm{R} \$ 2.800,00$ & $16,33 \%$ & $\mathrm{R} \$ 457,24$ & $\mathrm{R} \$ 511,34$ \\
\hline $\mathrm{abr} / 18$ & $\mathrm{R} \$ 6.510,00$ & $16,33 \%$ & $\mathrm{R} \$ 1.063,08$ & $\mathrm{R} \$ 511,34$ \\
\hline mai $/ 18$ & $\mathrm{R} \$ 3.892,00$ & $16,33 \%$ & $\mathrm{R} \$ 635,56$ & $\mathrm{R} \$ 511,34$ \\
\hline jun/18 & $\mathrm{R} \$ 5.801,25$ & $16,33 \%$ & $\mathrm{R} \$ 9473,34$ & $\mathrm{R} \$ 511,34$ \\
\hline TOTAL & $\mathbf{R} \$ \mathbf{2 2 . 6 5 1 , 2 5}$ & TOTAL & $\mathbf{R} \$ \mathbf{3 . 6 9 8 , 9 5}$ & $\mathbf{R} \$ \mathbf{3 . 0 6 8 , 0 6}$ \\
\hline
\end{tabular}

Fonte: Dados da pesquisa (2018)

No primeiro semestre de 2018, o percentual dos tributos incidentes apenas sobre a receita de prestação de serviço equivale a 16,33\%, o mesmo percentual em relação ao ano anterior. Isso porque a legislação relativa ao Lucro Presumido não foi alterada para o ano de 2018. Desta forma, permaneceram as mesmas alíquotas utilizadas pelo contribuinte no ano de 2017. No entanto, com o reajusto do salário mínimo que em 2017 era de $\mathrm{R} \$ 937,00$ e a partir de $1^{\circ}$ de janeiro de 2018 passou a ser de $\mathrm{R} \$ 954,00$, o valor dos encargos sobre folha de pagamento aumentou. No segundo semestre de 2017, o valor pago relativo a encargos sobre a folha de pagamento totalizou $\mathrm{R} \$ 3.013,38$, já no primeiro semestre de 2018 o valor total equivale a $\mathrm{R} \$ 3.068,06$, um total de $\mathrm{R} \$ 54,68$ a mais quando comparado o segundo semestre de 2017. 
Rosa, F. C., Mandu, T. O., Grecco, M. C. P., Silva, F. L., Antunes, M. T. P.; Relação entre o Valor Adicionado distribuído e a satisfação dos Funcionários

\subsection{Simples Nacional de acordo com a $L C n^{0}$ 123/06 x Lucro Presumido}

O planejamento tributário, como meio legal para diminuir a carga tributária, será analisado a partir da tabela 5. Conforme Rodrigues (2013), o planejamento tributário nada mais é, senão, um conjunto de medias que visam à economia de tributos. Desta forma, a tabela 5 demonstra o quanto pagará de tributos caso a empresa opte pelo Simples Nacional ou Lucro Presumido como forma de recolhimento dos seus tributos, considerando a mesma receita bruta para o período analisado.

Tabela 5 - Simples Nacional de acordo com a LC nº 123/06 x Lucro Presumido

\begin{tabular}{c|c|c|c|c|c}
\hline \multicolumn{2}{l}{ DADOS } & $\begin{array}{c}\text { SIMPLES NACIONAL LC N } \\
\mathbf{1 2 3 / 0 6}\end{array}$ & \multicolumn{2}{c}{ LUCRO PRESUMIDO $^{2}$} \\
\hline MÊS-ANO & RECEITA BRUTA & ALÍQUOTA & TRIBUTOS & ALÍQUOTA & TRIBUTOS \\
\hline jul/17 & $\mathrm{R} \$ 9.812,00$ & $16,93 \%$ & $\mathrm{R} \$ 1.661,17$ & $16,33 \%$ & $\mathrm{R} \$ 1.602,30$ \\
\hline ago/17 & $\mathrm{R} \$ 12.006,00$ & $16,93 \%$ & $\mathrm{R} \$ 2.032,62$ & $16,33 \%$ & $\mathrm{R} \$ 1.960,58$ \\
\hline set/17 & $\mathrm{R} \$ 10.816,00$ & $16,93 \%$ & $\mathrm{R} \$ 1.831,15$ & $16,33 \%$ & $\mathrm{R} \$ 1.766,25$ \\
\hline out/17 & $\mathrm{R} \$ 16.006,00$ & $16,93 \%$ & $\mathrm{R} \$ 2.709,82$ & $16,33 \%$ & $\mathrm{R} \$ 2.613,78$ \\
\hline nov/17 & $\mathrm{R} \$ 0,00$ & $16,93 \%$ & $\mathrm{R} \$ 0,00$ & $16,33 \%$ & $\mathrm{R} \$ 0,00$ \\
\hline dez/17 & $\mathrm{R} \$ 8.882,00$ & $16,93 \%$ & $\mathrm{R} \$ 1.503,72$ & $16,33 \%$ & $\mathrm{R} \$ 1.450,43$ \\
\hline TOTAL & $\mathbf{R} \$ \mathbf{5 7 . 5 2 2 , 0 0}$ & TOTAL & $\mathbf{R} \$ \mathbf{9 . 7 3 8 , 4 7}$ & TOTAL & $\mathbf{R} \$ \mathbf{9 . 3 9 3 , 3 4}$ \\
\hline Fon
\end{tabular}

Fonte: Dados da pesquisa (2018)

Considerando que a tabela demonstrou apenas os valores dos tributos a recolher sobre a receita de prestação de serviço de Fonoaudiologia, o regime tributário mais vantajoso para a empresa inicialmente é o Lucro Presumido. Isso porque, o percentual total de todos os tributos sobre a receita de prestação de serviço conforme o Lucro Presumido totaliza $16,33 \%$, ou $\mathrm{R} \$ 9.393,34$ de tributos a recolher.

Já no regime Simples Nacional, a alíquota inicial do anexo VI (anexo que contempla a atividade de Fonoaudiologia) de acordo com a LC n ${ }^{\circ} 123 / 06$, é de 16,93\%, totalizando $\mathrm{R} \$ 9.738,47$ de tributos a recolher. Desta forma, no Simples Nacional, o contribuinte paga o equivalente a $0,6 \%$ a mais que no Lucro Presumido. A economia tributária total, caso o contribuinte opte pelo regime de apuração Lucro Presumido, representa $R \$ 345,13$ no período analisado. No entanto, quando considerado o valor a ser pago de encargos sobre a folha de pagamento a título de pró-labore, o Lucro Presumido deixa de ser o regime mais benéfico, conforme a tabela 6:

Tabela 6 - Simples Nacional de acordo com a LC n 123/06 x Lucro Presumido

\begin{tabular}{c|c|c|c|c|c|c}
\hline \multicolumn{2}{c}{ DADOS } & $\begin{array}{c}\text { SIMPLES NACIONAL } \\
\text { LC N } \mathbf{1 2 3 / 0 6}\end{array}$ & \multicolumn{3}{c}{ LUCRO PRESUMIDO } \\
\hline MÊS-ANO & RECEITA BRUTA & ALÍQUOTA & TRIBUTOS & ALÍQUOTA & TRIBUTOS & INSS (26,8\%) \\
\hline jul/17 & $\mathrm{R} \$ 9.812,00$ & $16,93 \%$ & $\mathrm{R} \$ 1.661,17$ & $16,33 \%$ & $\mathrm{R} \$ 1.602,30$ & $\mathrm{R} \$ 502,23$ \\
\hline $\mathrm{ago} / 17$ & $\mathrm{R} \$ 12.006,00$ & $16,93 \%$ & $\mathrm{R} \$ 2.032,62$ & $16,33 \%$ & $\mathrm{R} \$ 1.960,58$ & $\mathrm{R} \$ 502,23$ \\
\hline set/17 & $\mathrm{R} \$ 10.816,00$ & $16,93 \%$ & $\mathrm{R} \$ 1.831,15$ & $16,33 \%$ & $\mathrm{R} \$ 1.766,25$ & $\mathrm{R} \$ 502,23$ \\
\hline out/17 & $\mathrm{R} \$ 16.006,00$ & $16,93 \%$ & $\mathrm{R} \$ 2.709,82$ & $16,33 \%$ & $\mathrm{R} \$ 2.613,78$ & $\mathrm{R} \$ 502,23$ \\
\hline
\end{tabular}


Rosa, F. C., Mandu, T. O., Grecco, M. C. P., Silva, F. L., Antunes, M. T. P.; Relação entre o Valor Adicionado distribuído e a satisfação dos Funcionários

\begin{tabular}{c|c|c|c|c|c|c}
\hline nov/17 & $\mathrm{R} \$ 0,00$ & $16,93 \%$ & $\mathrm{R} \$ 0,00$ & $16,33 \%$ & $\mathrm{R} \$ 0,00$ & $\mathrm{R} \$ 502,23$ \\
\hline dez/17 & $\mathrm{R} \$ 8.882,00$ & $16,93 \%$ & $\mathrm{R} \$ 1.503,72$ & $16,33 \%$ & $\mathrm{R} \$ 1.450,43$ & $\mathrm{R} \$ 502,23$ \\
\hline TOTAL & R\$ 57.522,00 & TOTAL & R\$ 9.738,47 & TOTAL & $\mathbf{R} \$ \mathbf{9 . 3 9 3 , 3 4}$ & $\mathbf{R} \$ \mathbf{3 . 0 1 3 , 3 8}$ \\
\hline
\end{tabular}

Fonte: Dados da pesquisa (2018)

Quando considerado todos os tributos, tanto os incidentes sobre a receita de prestação de serviço de Fonoaudiologia quanto os encargos incidentes sobre a folha de pagamento, o Lucro Presumido não é mais a melhor opção para a empresa. Caso opte pelo Lucro Presumido, o valor pago de tributos é de R\$12.406,73, representando R\$ 2.668,26 a mais de tributos em relação ao Simples Nacional. Isso se deve ao fato das empresas optantes pelo Simples Nacional serem isentas do recolhimento dos encargos incidentes sobre a folha de pagamento a título de Outras Entidades e RAT ajustada. Os optantes pelo Simples Nacional recolhem apenas a Contribuição Previdenciária Patronal (CPP) inclusa na guia única de recolhimento dos tributos do Simples Nacional.

\subsection{Simples Nacional de acordo com a LC n ${ }^{0} 155 / 16$ x Lucro Presumido}

A tabela 7 demonstra o comparativo entre o Simples Nacional de acordo com as alterações realizadas pela $\mathrm{LC} \mathrm{n}^{\circ} 155 / 16$, que entraram em vigor em $1^{\circ}$ de janeiro de 2018 . Os percentuais do Lucro Presumido permaneceram os mesmos do ano de 2017. Já o percentual do Simples Nacional foi reduzindo em relação ao ano anterior. Conforme foi analisado anteriormente, inicialmente foram considerados apenas os tributos incidentes sobre a prestação de serviço de Fonoaudiologia. No segundo momento foram considerados todos os tributos, tanto os incidentes sobre a receita bruta de prestação de serviço, quanto os encargos sobre folha de pagamento.

Tabela 7 - Simples Nacional de acordo com a LC no 155/16 x Lucro Presumido

\begin{tabular}{c|c|c|c|c|c}
\hline \multicolumn{2}{c|}{ DADOS } & \multicolumn{2}{c|}{$\begin{array}{c}\text { SIMPLES NACIONAL LC N } \\
\mathbf{1 5 5 / 1 6}\end{array}$} & \multicolumn{2}{c}{ LUCRO PRESUMIDO } \\
\hline MÊS-ANO & RECEITA BRUTA & ALÍQUOTA & TRIBUTOS & ALÍQUOTA & TRIBUTOS \\
\hline jan/18 & $\mathrm{R} \$ 3.648,00$ & $15,50 \%$ & $\mathrm{R} \$ 565,44$ & $16,33 \%$ & $\mathrm{R} \$ 595,72$ \\
\hline $\mathrm{fev} / 18$ & $\mathrm{R} \$ 0,00$ & $15,50 \%$ & $\mathrm{R} \$ 0,00$ & $16,33 \%$ & $\mathrm{R} \$ 0,00$ \\
\hline $\mathrm{mar} / 18$ & $\mathrm{R} \$ 2.800,00$ & $15,50 \%$ & $\mathrm{R} \$ 434,00$ & $16,33 \%$ & $\mathrm{R} \$ 457,24$ \\
\hline $\mathrm{abr} / 18$ & $\mathrm{R} \$ 6.510,00$ & $15,50 \%$ & $\mathrm{R} \$ 1.009,05$ & $16,33 \%$ & $\mathrm{R} \$ 1.063,08$ \\
\hline mai $/ 18$ & $\mathrm{R} \$ 3.892,00$ & $15,50 \%$ & $\mathrm{R} \$ 603,26$ & $16,33 \%$ & $\mathrm{R} \$ 635,56$ \\
\hline jun/18 & $\mathrm{R} \$ 5.801,25$ & $15,50 \%$ & $\mathrm{R} \$ 899,19$ & $16,33 \%$ & $\mathrm{R} \$ 947,34$ \\
\hline TOTAL & $\mathbf{R} \$ \mathbf{2 2 . 6 5 1 , 2 5}$ & TOTAL & $\mathbf{R} \$ \mathbf{3 . 5 1 0 , 9 4}$ & TOTAL & $\mathbf{R} \$ \mathbf{3 . 6 9 8 , 9 5}$ \\
\hline
\end{tabular}

Fonte: Dados da pesquisa (2018)

Percebe-se que, diferentemente da análise anterior, quando considerado apenas os tributos incidentes sobre a receita de prestação de serviços, o Lucro Presumido não é mais a melhor opção para a empresa apurar seus tributos. Tal fato é explicado devido à extinção do anexo VI, que tinha alíquota inicial de 16,93\%. A partir da vigência da LC $\mathrm{n}^{\mathrm{o}} 155 / 16$, a atividade de Fonoaudiologia passou a ser tributado conforme o anexo III ou V. A empresa está enquadrado no anexo $\mathrm{V}$, em sua primeira faixa, com alíquota de 15,50\%, uma vez que seu Fator R é inferior a 0,28 ou 28\%. Quando compara a carga tributária sobre a receita de prestação de serviço, bem como os encargos sobre a folha de pagamento, o Lucro Presumido torna-se ainda mais inviável, conforme demonstra a tabela 8: 
Rosa, F. C., Mandu, T. O., Grecco, M. C. P., Silva, F. L., Antunes, M. T. P.; Relação entre o Valor Adicionado distribuído e a satisfação dos Funcionários

Tabela 8 - Simples Nacional de acordo com a LC no 155/16 x Lucro Presumido

\begin{tabular}{c|c|c|c|c|c|c}
\hline \multicolumn{2}{c|}{ DADOS } & $\begin{array}{r}\text { SIMPLES NACIONAL } \\
\text { LC N }\end{array}$ & \multicolumn{3}{c}{ LUCRO PRESUMIDO } \\
\hline MÊS-ANO & RECEITA BRUTA & ALÍQUOTA & TRIBUTOS & ALÍQUOTA & TRIBUTOS & INSS (26,8\%) \\
\hline jan/18 & $\mathrm{R} \$ 3.648,00$ & $15,50 \%$ & $\mathrm{R} \$ 565,44$ & $16,33 \%$ & $\mathrm{R} \$ 595,72$ & $\mathrm{R} \$ 511,34$ \\
\hline fev/18 & $\mathrm{R} \$ 0,00$ & $15,50 \%$ & $\mathrm{R} \$ 0,00$ & $16,33 \%$ & $\mathrm{R} \$ 0,00$ & $\mathrm{R} \$ 511,34$ \\
\hline mar/18 & $\mathrm{R} \$ 2.800,00$ & $15,50 \%$ & $\mathrm{R} \$ 434,00$ & $16,33 \%$ & $\mathrm{R} \$ 457,24$ & $\mathrm{R} \$ 511,34$ \\
\hline abr/18 & $\mathrm{R} \$ 6.510,00$ & $15,50 \%$ & $\mathrm{R} \$ 1.009,05$ & $16,33 \%$ & $\mathrm{R} \$ 1.063,08$ & $\mathrm{R} \$ 511,34$ \\
\hline mai/18 & $\mathrm{R} \$ 3.892,00$ & $15,50 \%$ & $\mathrm{R} \$ 603,26$ & $16,33 \%$ & $\mathrm{R} \$ 635,56$ & $\mathrm{R} \$ 511,34$ \\
\hline jun/18 & $\mathrm{R} \$ 5.801,25$ & $15,50 \%$ & $\mathrm{R} \$ 899,19$ & $16,33 \%$ & $\mathrm{R} \$ 947,34$ & $\mathrm{R} \$ 511,34$ \\
\hline TOTAL & R \$ 22.651,25 & TOTAL & R\$ 3.510,94 & TOTAL & R\$ 3.698,95 & R\$ 3.068,06 \\
\hline
\end{tabular}

Fonte: Dados da pesquisa (2018)

Caso opte pelo regime Lucro Presumido, a diferença relativa aos tributos a recolher em comparação ao Simples Nacional, considerando tantos os tributos sobre a receita bruta de prestação de serviço quando os encargos sobre a folha de pagamento totalizam $\mathrm{R} \$ 3.256,07$. Tal valor representa que o contribuinte pagaria quase o dobro de tributos optando pelo Lucro Presumido como forma de apuração dos seus tributos, ao invés da opção pelo Simples Nacional. Portanto, a partir da vigência da LC n ${ }^{\circ} 155 / 16$, o regime mais benéfico para a empresa estudada é o Simples Nacional.

\subsection{Folha de Pagamento, Encargos e Fator R Inferior a $28 \%$}

A tabela 9 demonstra o percentual do Fator R nos 12 meses analisados na pesquisa, bem como o valor total de folha de pagamento e encargos do mesmo período. Foi analisada a variação do percentual do Fator R. Ressalta-se que as despesas com folha de pagamento foram decorrentes do pagamento mensal de pró-labore equivalente a dois salários mínimos vigentes à época.

\begin{tabular}{|c|c|c|c|c|}
\hline ANO-MÊS & FOLHA DE PAGAMENTO & CPP & TOTAL & FATOR R \\
\hline jul/17 & $\mathrm{R} \$ 1.874,00$ & $\mathrm{R} \$ 32,96$ & $\mathrm{R} \$ 1.906,96$ & $26,48 \%$ \\
\hline ago/17 & $\mathrm{R} \$ 1.874,00$ & $\mathrm{R} \$ 40,33$ & $\mathrm{R} \$ 1.914,33$ & $27,34 \%$ \\
\hline set/17 & $\mathrm{R} \$ 1.874,00$ & $\mathrm{R} \$ 36,33$ & $\mathrm{R} \$ 1.910,33$ & $27,31 \%$ \\
\hline out/17 & $\mathrm{R} \$ 1.874,00$ & $\mathrm{R} \$ 55,78$ & $\mathrm{R} \$ 1.929,78$ & $24,24 \%$ \\
\hline nov/17 & $\mathrm{R} \$ 1.874,00$ & $\mathrm{R} \$ 0,00$ & $\mathrm{R} \$ 1.874,00$ & $25,56 \%$ \\
\hline dez/17 & $\mathrm{R} \$ 1.874,00$ & $\mathrm{R} \$ 29,83$ & $\mathrm{R} \$ 1.903,83$ & $27,68 \%$ \\
\hline jan/18 & $\mathrm{R} \$ 1.908,00$ & $\mathrm{R} \$ 94,99$ & $\mathrm{R} \$ 2.002,99$ & $27,00 \%$ \\
\hline $\mathrm{fev} / 18$ & $\mathrm{R} \$ 1.908,00$ & $\mathrm{R} \$ 0,00$ & $\mathrm{R} \$ 1.908,00$ & $27,21 \%$ \\
\hline $\mathrm{mar} / 18$ & $\mathrm{R} \$ 1.908,00$ & $\mathrm{R} \$ 125,21$ & $\mathrm{R} \$ 2.033,21$ & $27,24 \%$ \\
\hline $\mathrm{abr} / 18$ & $\mathrm{R} \$ 1.908,00$ & $\mathrm{R} \$ 291,11$ & $\mathrm{R} \$ 2.199,11$ & $26,57 \%$ \\
\hline mai/18 & $\mathrm{R} \$ 1.908,00$ & $\mathrm{R} \$ 174,04$ & $\mathrm{R} \$ 2.082,04$ & $27,03 \%$ \\
\hline jun/18 & $\mathrm{R} \$ 1.908,00$ & $\mathrm{R} \$ 259,42$ & $\mathrm{R} \$ 2.167,42$ & $27,35 \%$ \\
\hline TOTAL & $\mathrm{R} \$ 22.692,00$ & R\$ $1.140,00$ & R\$ 23.832,00 & - \\
\hline
\end{tabular}

Fonte: Dados da pesquisa (2018)

O acompanhamento do Fator R a partir da vigência da $\mathrm{LC}^{\circ}{ }^{\circ} 155 / 16$ é extremamente importante para a empresa. Isso porque quanto menor for o resultado do Fator $\mathrm{R}$, maior será a 
Rosa, F. C., Mandu, T. O., Grecco, M. C. P., Silva, F. L., Antunes, M. T. P.; Relação entre o Valor Adicionado distribuído e a satisfação dos Funcionários

alíquota ser cobrada, ou seja, quanto menor a representatividade da folha de pagamento em relação à receita bruta acumulado, maior será a alíquota aplicada. Conforme os dados analisados no período, o valor total pago referente à folha de pagamento e encargos foi de $\mathrm{R} \$ 23.832,00$. Já o Fator R teve variação entre $24,00 \%$ a 27,68\%, estando próximo a $28 \%$.

\subsection{Folha de Pagamento, Encargos e Simulação do Fator $R \geq 28 \%$}

A tabela 10 traz a simulação do aumento do pró-labore. No ano de 2017 o valor pago a título de pró-labore era equivalente a dois salários mínimos. Sendo este aumentado para dois salários mínimos e meio no último trimestre de 2017, o Fator R da empresa ultrapassaria $28 \%$ a partir de dezembro de 2017.

Tabela 10 - Folha de Pagamento, Encargos e Fator R

\begin{tabular}{c|c|c|c|c}
\hline ANO-MES & FOLHA DE PAGAMENTO & CPP & TOTAL & FATOR R \\
\hline jul/17 & $\mathrm{R} \$ 1.874,00$ & $\mathrm{R} \$ 32,96$ & $\mathrm{R} \$ 1.906,96$ & $26,48 \%$ \\
\hline ago/17 & $\mathrm{R} \$ 1.874,00$ & $\mathrm{R} \$ 40,33$ & $\mathrm{R} \$ 1.914,33$ & $27,34 \%$ \\
\hline set/17 & $\mathrm{R} \$ 1.874,00$ & $\mathrm{R} \$ 36,33$ & $\mathrm{R} \$ 1.910,33$ & $27,31 \%$ \\
\hline out/17 & $\mathrm{R} \$ 2.342,50$ & $\mathrm{R} \$ 55,78$ & $\mathrm{R} \$ 2.398,28$ & $24,24 \%$ \\
\hline nov/17 & $\mathrm{R} \$ 2.342,50$ & $\mathrm{R} \$ 0,00$ & $\mathrm{R} \$ 2.342,50$ & $25,56 \%$ \\
\hline dez/17 & $\mathrm{R} \$ 2.342,50$ & $\mathrm{R} \$ 29,83$ & $\mathrm{R}$ 2.372,33 & $28,72 \%$ \\
\hline jan/18 & $\mathrm{R} \$ 1.908,00$ & $\mathrm{R} \$ 94,99$ & $\mathrm{R} \$ 2.002,99$ & $28,51 \%$ \\
\hline fev/18 & $\mathrm{R} \$ 1.908,00$ & $\mathrm{R} \$ 0,00$ & $\mathrm{R} \$ 1.908,00$ & $28,76 \%$ \\
\hline mar/18 & $\mathrm{R} \$ 1.908,00$ & $\mathrm{R} \$ 125,21$ & $\mathrm{R} \$ 2.033,21$ & $29,87 \%$ \\
\hline abr/18 & $\mathrm{R} \$ 1.908,00$ & $\mathrm{R} \$ 291,11$ & $\mathrm{R} \$ 2.199,11$ & $31,28 \%$ \\
\hline mai/18 & $\mathrm{R} \$ 1.908,00$ & $\mathrm{R} \$ 174,04$ & $\mathrm{R} \$ 2.082,04$ & $28,61 \%$ \\
\hline jun/18 & $\mathrm{R} \$ 1.908,00$ & $\mathrm{R} \$ 259,42$ & $\mathrm{R} \$ 2.167,42$ & $31,10 \%$ \\
\hline TOTAL & $\mathrm{R} \$ \mathbf{2 4 . 0 9 7 , 5 0}$ & $\mathrm{R} \$ \mathbf{1 . 1 4 0 , 0 0}$ & $\mathrm{R} \$ \mathbf{2 5 . 2 3 7 , 5 0}$ & - \\
\hline
\end{tabular}

Fonte: Dados da pesquisa (2018)

Nota-se que, majorando o pró-labore no último trimestre de 2017, que era de $\mathrm{R} \$$ 1.874,00, equivalente a dois salários mínimos, para dois salários mínimos e meio, o Fator $\mathrm{R}$ no ano de 2018 passaria a ficar superior a 28\%. Tal medida faria com que a empresa estudada passasse a recolher seus tributos conforme o anexo III, sendo este menos oneroso que o anexo V. Com a elevação do pró-labore, o total de despesas com folha de pagamento e encargos aumentaria em $\mathrm{R} \$ 1.405,50$.

\subsection{Simples Nacional de acordo com a $L C n^{\circ} 155 / 16-28 \% \leq$ Fator $R<28 \%$}

Na tabela 11 foi comparada a tributação conforme o Simples Nacional e de acordo com a $\mathrm{LC} \mathrm{n}^{\circ} 155 / 16$, com o Fator R estando igual ou superior a $28 \%$, bem como o Fator R Inferior a $28 \%$.

Tabela 11 - Simples Nacional de acordo com a LC n ${ }^{\circ}$ 155/16 e Fator R

\begin{tabular}{|c|c|c|c|c|c}
\hline \multicolumn{2}{|c|}{ DADOS } & $\begin{array}{c}\text { SIMPLES NACIONAL LC N } \\
155 / 16\end{array}$ & $\begin{array}{c}\text { FIMPLES R }<28 \% \\
\text { SIMAS NACIONAL LC N }\end{array}$ \\
\hline MÊS-ANO & RECEITA BRUTA & ALÍQUOTA & TRIBUTOS & ALÍQUOTA $\geq 28 \%$ & TRIBUTOS \\
\hline
\end{tabular}

Redeca, v.6, n.2. Jul-Dez. 2019 p. 103-127. 
Rosa, F. C., Mandu, T. O., Grecco, M. C. P., Silva, F. L., Antunes, M. T. P.; Relação entre o Valor Adicionado distribuído e a satisfação dos Funcionários

\begin{tabular}{c|c|c|c|c|c}
\hline jan/18 & $\mathrm{R} \$ 3.648,00$ & $15,50 \%$ & $\mathrm{R} \$ 565,44$ & $6,00 \%$ & $\mathrm{R} \$ 218,88$ \\
\hline $\mathrm{fev} / 18$ & $\mathrm{R} \$ 0,00$ & $15,50 \%$ & $\mathrm{R} \$ 0,00$ & $6,00 \%$ & $\mathrm{R} \$ 0,00$ \\
\hline $\mathrm{mar} / 18$ & $\mathrm{R} \$ 2.800,00$ & $15,50 \%$ & $\mathrm{R} \$ 434,00$ & $6,00 \%$ & $\mathrm{R} \$ 168,00$ \\
\hline $\mathrm{abr} / 18$ & $\mathrm{R} \$ 6.510,00$ & $15,50 \%$ & $\mathrm{R} \$ 1.009,05$ & $6,00 \%$ & $\mathrm{R} \$ 390,60$ \\
\hline mai/18 & $\mathrm{R} \$ 3.892,00$ & $15,50 \%$ & $\mathrm{R} \$ 603,26$ & $6,00 \%$ & $\mathrm{R} \$ 233,52$ \\
\hline jun/18 & $\mathrm{R} \$ 5.801,25$ & $15,50 \%$ & $\mathrm{R} \$ 899,19$ & $6,00 \%$ & $\mathrm{R} \$ 348,08$ \\
\hline TOTAL & $\mathrm{R} \$ \mathbf{2 2 . 6 5 1 , 2 5}$ & TOTAL & $\mathbf{R} \$ \mathbf{3 . 5 1 0 , 9 4}$ & TOTAL & $\mathbf{R} \$ \mathbf{1 . 3 5 9 , 0 8}$ \\
\hline
\end{tabular}

Fonte: Dados da pesquisa (2018)

De acordo com a tabela 11, constata-se que a melhor maneira para empresa estudada apurar seus tributos no ano de 2018 é optando pelo Simples Nacional e com o Fator R igual ou superior a $28 \%$. A economia tributária para a empresa estando com o Fator R igual ou superior a $28 \%$ no ano de 2018 seria de $\mathrm{R} \$ 2.151,86$, ou seja, uma redução em mais $60 \%$ do valor dos tributos a recolher. Com o aumento do pró-labore e, consequentemente, o aumento das despesas com folha de pagamento em $\mathrm{R} \$ 1.405,50$, a efetiva economia para a empresa seria de $\mathrm{R} \$ 746,36$ no período analisado.

\section{Considerações Finais}

De fato, as mudanças tributárias tendem a exercer grande influência sobre o processo de continuidade de uma organização, portanto torna-se necessário que as decisões quanto à escolha do regime de tributação sejam realizadas de forma cautelosa e planejada. Uma vez que, a atribuição de uma nova regra de tributação, quando benéfica para a empresa, torna-se crucial para a saúde dos negócios. Destaca-se ainda, que o surgimento de novas regras tributárias passa a servir de canal para outras, competindo ao empresário optar pela qual the trará maiores vantagens, não só em relação às cargas tributárias, como também quanto às obrigações acessórias. Diante disso, com base nas mudanças realizadas no regime de tributação Simples Nacional através da LC no 155/16, o estudo buscou analisar a melhor maneira para um empresário individual, prestador de serviço de Fonoaudiologia e situado na cidade de Mossoró/RN apurar seus tributos. Para alcançar tal objetivo, fez-se necessário verificar a tributação da empresa entre os meses de julho de 2017 a junho de 2018, bem como, comparar os regimes tributários Lucro Presumido e Simples Nacional.

Partindo das análises realizadas quanto a tributação da empresa objeto do estudo, bem como as simulações e comparações efetuadas, percebeu-se que a viabilidade do sistema de tributação Simples Nacional proporciona grandes impactos no resultado final da empresa. Isso porque, a empresa necessita do auxilio principalmente na área fiscal para que possa se firmar no mercado, ter continuidade e crescimento por meio do tratamento diferenciado proporcionado pelo Simples Nacional. O planejamento tributário bem formulado é de fundamental importância para as microempresas e empresas de pequeno porte, tornando a atividade cada vez mais viável e contribuindo para que a empresa se mantenha viva em um mercado cada vez mais competitivo. No que tange o objetivo geral, chegou-se a conclusão que, para a empresa objeto da análise do estudo de caso apresentado neste trabalho, dentre os regimes analisados, a melhor maneira para a empresa apurar seus tributos é optando pelo Simples Nacional e com o Fator R igual ou superior a $28 \%$. Desta forma, caso a empresa tenha gastos com folha de pagamento e encargos superior a $28 \%$ a redução será significativa e a diferença representa uma redução em mais $60 \%$ em tributos a recolher. 
Rosa, F. C., Mandu, T. O., Grecco, M. C. P., Silva, F. L., Antunes, M. T. P.; Relação entre o Valor Adicionado distribuído e a satisfação dos Funcionários

Com relação às limitações de estudo, este trabalho limita-se quanto à receita bruta auferida e quanto ao valor da folha de pagamento e os encargos nela incidentes. Uma vez que a receita bruta auferida e o valor da folha de pagamento interferem diretamente no cálculo e apuração dos tributos, o resultado aqui obtido não pode ser levado para outras empresas que venham a ser tributado com base no Anexo V da LC n ${ }^{\circ}$ 155/16. Antes de tudo, é preciso verificar tais fatores, pois, dependendo do caso, o Lucro Presumido poderá se tornar a melhor opção para a empresa apurar seus tributos. Sugere-se como estudos futuros, a extensão da analise em outras empresas optantes pelo Simples Nacional e enquadradas no anexo V. Assim como, a comparação dos resultados obtidos neste trabalho como o regime de tributação Lucro Real, visando verificar se haverá mudança na escolha do regime tributário.

\section{Referências}

ANDRADE FILHO, Edmar Oliveira. Imposto de Renda das Empresas. $7^{\text {a }}$ ed. São Paulo: Atlas, 2010.

ANDRADE, Juliana Santos de. Vantagens e desvantagens do Simples Nacional. 2010.

BRASIL. Decreto Lei $\mathbf{n}^{0} 5.844$ de 23 de setembro de 1943. Dispões sobre a cobrança e fiscalização do imposto de renda. Disponível em:

http://www.planalto.gov.br/ccivil_03/decreto-Lei/Del5844.htm. Acesso em: 10. Jun. 2018.

BRASIL. Decreto Lei no 1.589 de 26 de dezembro de 1977. Altera a legislação do imposto sobre a renda. Disponível em: http://www.planalto.gov.br/CCIVIL_03/Decreto-

Lei/Del1598.htm. Acesso em: 11. Jun. 2018.

BRASIL. Constituição da República Federativa do Brasil, de 1988. Disponível em: http://www.planalto.gov.br/ccivil_03/Constituicao/Constituicao.htm. Acesso em: 05 Mai. 2018.

BRASIL. Lei no 8.891, de 20 de janeiro de 1995. Altera a Legislação Tributária Federal e dá outras providências. Disponível em: http://www.planalto.gov.br/ccivil_03/LEIS/L8981.htm. Acesso em: 22. Jun. 2018.

BRASIL. Lei $\mathbf{n}^{0} 9.317$ de 05 de dezembro de 1996. Dispõe sobre o regime tributário das microempresas e das empresas de pequeno porte, institui o Sistema Integrado de Pagamento de Impostos e Contribuições das Microempresas e das Empresas de Pequeno Porte SIMPLES e dá outras providências. Disponível em: http://www.planalto.gov.br/ccivil_03/LEIS/L9317.htm. Acesso em: 29. Jun. 2018.

BRASIL. Lei no 9.718, de 27 de novembro de 1998. Altera a Legislação Tributária Federal. Disponível em: http://www.planalto.gov.br/ccivil_03/LEIS/L9718.htm. Acesso em: 22. Jun. 2018.

BRASIL. Decreto Lei no 3.000 de 26 de março de 1999. Regulamenta a tributação, fiscalização, arrecadação e administração do Imposto sobre a Renda e Proventos de Qualquer Natureza. Disponível em: http://www.planalto.gov.br/ccivil_03/Decreto/D3000.htm. Acesso em: 15. Jun. 2018. 
Rosa, F. C., Mandu, T. O., Grecco, M. C. P., Silva, F. L., Antunes, M. T. P.; Relação entre o Valor Adicionado distribuído e a satisfação dos Funcionários

BRASIL. Lei Complementar $\mathbf{n}^{\mathbf{0}}$ 123, de 14 de dezembro de 2006. Estatuto Nacional da Microempresa e da Empresa de Pequeno Porte. Disponível em:

http://www.planalto.gov.br/ccivil_03/leis/LCP/Lcp123.htm Acesso em: 05 Mai. 2018.

BRASIL. Lei Complementar $n^{\mathbf{0}} \mathbf{1 2 8}$, de 19 de dezembro de 2008. Altera a Lei

Complementar $\mathrm{n}^{\circ}$ 123/06. Disponível em:

http://www.planalto.gov.br/ccivil_03/leis/LCP/Lcp128.htm. Acesso em: 05. Mai. 2018.

BRASIL. Lei Complementar $n^{\circ}$ 147, de 7 de agosto de 2014. Altera a Lei Complementar $n^{\circ}$ 123/06. Disponível em: https://www.planalto.gov.br/ccivil_03/LEIS/LCP/Lcp147.htm. Acesso em: 05. Mai. 2018.

BRASIL. Lei Complementar $\mathbf{n}^{\mathbf{0}}$ 155, de 27 de outubro de 2016. Altera a Lei Complementar no 123/06. Disponível em: http://www.planalto.gov.br/ccivil_03/LEIS/LCP/Lcp155.htm. Acesso em: 06. Mai. 2018.

CHAVES, Francisco Coutinho. Contabilidade Tributária na Prática. São Paulo: Atlas, $1^{\text {a }}$ Ed. 2010.

CHAVES, Francisco Coutinho. Contabilidade Prática na Construção Civil: de acordo com as normas internacionais de contabilidade. São Paulo: Atlas, 2014.

CASTRO, Flávia de Almeida Viveiros de; OLIVEIRA NETO, Arnaldo Marques de; SOUZA JUNIOR, Artur Antonio Leite de; SOUSA FILHO, Rodolfo de Castro. GESTÃO e planejamento de tributos. Rio de Janeiro: FGV, 2007.

FABRETTI, Láudio Camargo. Direito tributário aplicado: impostos e contribuições das empresas. Editora Atlas, 2006.

GABRIEL, Paula Caroline. Desoneração tributária regime de tributação mais vantajoso para abertura de uma empresa no ramo da comunicação digital: Simples Nacional ou Lucro Presumido. Prêmio Simples Nacional e Empreendedorismo, Brasília: $1^{\text {a }}$ EDIÇÃO.

IUDÍCIBUS, Sérgio de et al. Manual de contabilidade societária. São Paulo: Atlas, v. 792, n. 3, 2010.

IBPT - Instituto Brasileiro de Planejamento e Tributação. Formação de Tributarista. Curso de Formação de Tributarista. 25 de Julho de 2015.

IBPT - Instituto Brasileiro de Planejamento e Tributação. CNPL: Brasil é o País que proporciona pior retorno em serviços públicos à sociedade. 2017. Disponível em: http://www.ibpt.com.br. Acesso em: 02 Mai. 2018.

MARCONI, Marina de Andrade; LAKATOS, Eva Maria. Técnicas de pesquisa. 5. Ed. São Paulo: Atlas, 2002.

MINISTERIO DA FAZENDA. Secretaria da Receita Federal do Brasil. Disponível em: http://idg.receita.fazenda.gov.br. Acesso em: 05 Mai. 2018. 
Rosa, F. C., Mandu, T. O., Grecco, M. C. P., Silva, F. L., Antunes, M. T. P.; Relação entre o Valor Adicionado distribuído e a satisfação dos Funcionários

OLIVEIRA, Luis Martins de; CHIEREGATO, Renato; PEREZ JUNIOR, José Hernandez; GOMES, Marliete Bezerra. Manual de contabilidade tributária. 12. ed. São Paulo: Editora Atlas, 2013. v. 1. p. 432.

OLIVEIRA, Rodrigo Rios Faria; GONÇALVES, Mariana. A importância do planejamento tributário para as empresas. Revista Científica e-Locução, v. 1, n. 3, 2015.

RAUPP, F. M.; BEUREN, Ilse M. Como elaborar trabalhos monográficos em contabilidade: teoria e prática.(3) São Paulo: Atlas. 2013.

RODRIGUES, Aldenir Ortiz. de et al. Aspectos Jurídicos Do Planejamento Tributário. 2. Ed. São Paulo: IOBFolhamatic, 2013.

SANTOS, Adiléia Ribeiro; OLIVEIRA, Rúbia Carla Mendes de. Planejamento tributário com ênfase em empresas optantes pelo lucro real. In: XVIII Congresso Nacional de

Contabilidade, RS, Gramado. 2008.

SILVA, J. Miguel; RODRIGUES, Agostinho Inácio. LALUR-Guia Prático de Escrituração do Livro de Apuração do Lucro Real 2006. São Paulo, Cenofisco, 2006.

THIRY-CHERQUES, Hermano Roberto; VIEIRA, M.; ZOUAN, D. Programa para aplicação às ciências da gestão de um método de caráter fenomenológico. VIEIRA, MM F; ZOUAIN, DM Pesquisa qualitativa em administração. Rio de Janeiro: FGV, 2004.

YOUNG, Lúcia Helena Briski. Lucro presumido. 8. ed., rev. atual. Curitiba, PR: Juruá, 2008, p. 36.

YOUNG, Lúcia Helena Briski. Planejamento Tributário-Coleção Prática Contábil-Fusão, Cisão e Incorporação. 4. ed., Revista e Ampliada. Jurua Editora, 2009.

WILBERT, Marcelo Driemeyer; DE ALCÂNTARA, Lucas Teles; SERRANO, André Luiz Marques. Impactos do simples na sociedade: uma análise da arrecadação e dos empregos gerados pelas microempresas, empresas de pequeno porte e pelos microempreendedores individuais-DOI: http://dx. doi. org/10.16930/2237-7662/rccc. v14n42p55-69. Revista

Catarinense da Ciência Contábil, v. 14, n. 42, p. 55-69, 2015. 